Article

\title{
Sources of Nutrients for High-Yielding Winter Oilseed Rape (Brassica napus L.) during Post-Flowering Growth
}

\author{
Witold Grzebisz ${ }^{1, *(D)}$, Witold Szczepaniak ${ }^{1}$ and Stanisław Grześ ${ }^{2}$ \\ 1 Department of Agricultural Chemistry and Environmental Biogeochemistry, \\ Poznan University of Life Sciences, Wojska Polskiego 28, 60-637 Poznan, Poland; \\ witold.szczepaniak@up.poznan.pl \\ 2 Department of Agronomy, Poznan University of Life Sciences, Wojska Polskiego 28, 60-637 Poznan, Poland; \\ stanislaw.grzes@up.poznan.pl \\ * Correspondence: witold.grzebisz@up.poznan.pl; Tel.: +48-618-48-77-88
}

Received: 5 April 2020; Accepted: 23 April 2020; Published: 28 April 2020

\begin{abstract}
Nutrient management by winter oilseed rape (WOSR) during the seed filling period (SFP) is crucial for seed density (SD), which subsequently determines seed yield (Y). This hypothesis was evaluated based on data from field experiments (2008-2010), with six treatments with sequentially added nutrients $(0, \mathrm{NP}, \mathrm{NPK}, \mathrm{NPKMgS1}(1 / 3$ total $\mathrm{MgS}$ rate - spring applied), NPKMgS2 (total MgS rate autumn applied); NPKMgS3 $(2 / 3$-autumn, $1 / 3$-spring). Nutrients accumulated in seeds were revealed as the most reliable WOSR trait, determining SD and Y. Yield was defined by the amounts of $\mathrm{K}$ and $\mathrm{Mg}$ in seeds. The amount nutrient remobilized from vegetative WOSR tissues was sufficient to cover the crop requirements during SFP for $\mathrm{N}, \mathrm{P}$, and $\mathrm{Zn}$, but not for $\mathrm{Ca}, \mathrm{K}, \mathrm{Mn}$, and $\mathrm{Cu}$. The post-flowering $\mathrm{K}$ uptake resulted in $\mathrm{PD}$, and $\mathrm{SD}$ increase, which subsequently resulted in a concomitant net uptake of $\mathrm{Ca}$ and $\mathrm{Mg}$. The excessive accumulation of $\mathrm{Ca}$, as well as $\mathrm{Cu}$, and $\mathrm{Mn}$ in seeds due to a shortage of $\mathrm{Mg}$, subsequently resulted in both SD and Y depression. The efficient exploitation of WOSR yielding potential as defined by $\mathrm{SD}$, is possible, provided during the SFP reveals a net $\mathrm{K}$ and $\mathrm{Mg}$ uptake.
\end{abstract}

Keywords: seed filling period; nutrient remobilization; nutrient post-flowering uptake; prognosis of yield components development; seed yield prognosis

\section{Introduction}

The importance of winter oilseed rape (WOSR) as a source of plant oil, which can be used for both food and bio-diesel production, as an example of a green energy source, is well known [1]. However, reasons for low yields, or their stagnation in the leading producers, are not well recognized [2,3]. Most scientific papers dealing with WOSR focus on key nutrients, such as N, P, K [4,5]. This, in fact, narrow fertilization concept, is true, provided there is a high soil fertility level, typical of old agricultural regions, like Europe. This species is currently cultivated over the entire world on soils, whose fertility level is far from meeting this crop requirement. As a result, yields are, in general, low, or only on a moderate level, as compared to the potential yield of this crop [2,6-8].

Modern WOSR technologies are based on new cultivars, high rates of $\mathrm{N}$, and respective protection against pathogens and insects $[9,10]$. The requirement of this crop for nutrients is high, including, in the first-line, N, $\mathrm{P}$, and K. At present, fertilization practices and nutrient application norms, developed in 80s of the 20th century, are too dated to fulfill WOSR requirements for nutrients. This not only refers to the $\mathrm{N}$ rate, but also to its timing and fertilizer choice [11,12]. An increasing seed yield also necessitates an increasing demand for $\mathrm{P}$, which accumulates mostly in seeds $[13,14]$. In addition, the increasing crop biomass, governed by $\mathrm{N}$ supply, requires a balanced supply of $\mathrm{K}$ [5]. Low soil 
$\mathrm{K}$ fertility is one of the most important nutritional factors limiting WOSR yields [15]. The WOSR requirement for sulfur is more widely recognized than that for magnesium, in spite of the fact that both nutrients are the most frequently applied as Kieserite or Epsom salt [16]. The breeding progress, resulting in new high-yielding cultivars, requires the development of efficient technologies primarily, including appropriate fertilization and balancing applied nitrogen $[9,17]$.

In general, there is a dominant opinion that the critical period of yield formation by WOSR, extends from the period covering the beginning of budding (BBCH 50) to full flowering [18,19]. Berry and Spink [2] extend this period to the end of the seed set. During this period, the key yield component is established, i.e., the number of seeds per plant, and consequently, the seed density (SD., i.e., number of seeds per $\mathrm{m}^{2}$ ). However, WOSR is highly sensitive to both abiotic and biotic stresses during the seed filling period (SFP), which starts with the onset of pod growth $[20,21]$. The strong competition between vegetative tissues, flower, and developing pods during the whole flowering phase, concomitant with the overlapping pod growth phase, results in an increasing sensitivity of plants to nutrient supply [22].

The previous study conducted by authors clearly showed that the exploitation of yielding potential of WOSR requires a deeper understanding into the processes responsible for nutrient management during the SFP $(13,24)$. The key question remains, however, to a great extent, whether the growth of pods and seeds depends on internal resources of nutrients during the SFP of WOSR development. It has been assumed that OSR vegetative tissues are a key source of nutrients for the growing pods and seeds, undergoing remobilization, at least partly, during the post-flowering stages of WOSR growth. This question can be formulated as follows: are the internal nutrient resources at the onset of flowering sufficient to meet the requirements of the growing seeds? The next, but also key question, refers to the uptake of nutrients directly from soil by plants during SFP. There arises a scientific problem about the impact of both nutrient pools on the degree of the size of yield components, i.e., sink capacity, as a prerequisite of seed yield.

It has been assumed that the nutrient balance conducted in the period, extending from the onset of flowering up to the physiological maturity of WOSR plants, is a reliable diagnostic tool to explain the reasons for the high variability in WOSR yields, both between regions, fields, and between years. The key objective of this study was to define the most reliable set of nutrients limiting the development of yield structure components and the yield itself. The detailed objective of the study was to evaluate the impact of balanced WOSR fertilization on the size of both internal (plant pre-flowering resources) and external pools (soil resources-post-flowering uptake) of nutrients on the pod density, seed density, thousand seed weight and finally, seed yield. The study should also lead to knowledge on the impact of a particular nutrient or its interaction on the sink/source relationships during the WOSR seed filling period.

\section{Materials and Methods}

\subsection{Experiments Set Up}

The primary sources of data used to prepare this manuscript are field experiments, which were carried out during the 2007/2008, 2008/2009, and 2009/2010 seasons in Donatowo ( $52^{\circ} 04^{\prime} \mathrm{N} ; 16^{\circ} 51^{\prime} \mathrm{E}$ ), Poland. The field experiment was conducted on soil with texture loamy sand in the top-soil over sandy loam, classified as Albic Luvisol. The content of the available nutrients (measured each year just after a forecrop harvesting from the soil depth of $0.2 \mathrm{~m}$ ) was in the medium/high/very high class, sufficient for high yielding WOSR (Table 1). Precipitation was variable from year to year $(20-461 \mathrm{~mm}$; 2008/2009-586 mm; 2009/2010 - 575 mm; 1957-201—527). It was normal during the first two seasons, except for April of $2008(60.4 \mathrm{~mm})$, and May $(82.2 \mathrm{~mm})$ and June $(99 \mathrm{~mm})$ of 2009, which were too wet. In the 2009/2010 season, the autumn was unusually moist, lessening plant resistance to frost, which in turn decreased plant density in the spring. 
Table 1. Agrochemical characteristics of the soil in the research plots.

\begin{tabular}{|c|c|c|c|c|c|c|c|c|}
\hline \multirow{2}{*}{ Year } & \multirow{2}{*}{$\begin{array}{c}\mathrm{pH} \\
(1 \mathrm{M} \mathrm{KCl})\end{array}$} & \multicolumn{6}{|c|}{ Content of Nutrients, $\mathrm{mg} \mathrm{kg}^{-1}$ Soil } & \multirow{2}{*}{$\frac{\mathrm{N}_{\text {min }}{ }^{3}}{\mathrm{~kg} \mathrm{ha}^{-1}}$} \\
\hline & & $\mathrm{P}_{2} \mathrm{O}_{5}{ }^{1}$ & Rating & $\mathrm{K}_{2} \mathrm{O}^{1}$ & Rating & $\mathrm{Mg}^{2}$ & Rating & \\
\hline 2008 & 6.36 & 221 & very high & 181 & high & 45 & medium & 65.6 \\
\hline 2009 & 6.55 & 204 & very high & 197 & high & 52 & high & 74.8 \\
\hline 2010 & 5.96 & 157 & high & 125 & medium & 75 & very high & 68.0 \\
\hline
\end{tabular}

1 according to the Egner-Riehm standard procedure; ${ }^{2}$ according to the Schachtschabel standard procedure; ${ }^{3} 0.01 \mathrm{CaCl}_{2}$ solution.

A field trial consisting of six treatments, differing in the composition of sequentially added sets of nutrients, arranged in a randomized complete block, and replicated four times, was the source of primary data for the study. The details of sequentially added nutrients and doses are described in Table 2 . Plants were fertilized with $\mathrm{N}$ (ammonium saltpeter, $34.0 \% \mathrm{~N}$ ), at a rate of $27 \mathrm{~kg} \mathrm{~N}^{-1}$ before sowing, $102 \mathrm{~kg} \mathrm{~N} \mathrm{ha}^{-1}$ before spring regrowth and $78 \mathrm{~kg} \mathrm{ha}^{-1}$ at BBCH 30 (end of March/beginning of April). Phosphorus $\left(69 \mathrm{~kg} \mathrm{P}_{2} \mathrm{O}_{5} \mathrm{ha}^{-1}\right.$, di-ammonium phosphate, $\left.18 \% \mathrm{~N}, 46 \% \mathrm{P}_{2} \mathrm{O}_{5}\right)$ and $\mathrm{K}\left(180 \mathrm{~kg} \mathrm{~K}_{2} \mathrm{O} \mathrm{ha}^{-1}\right.$, muriate of potash $\left(60 \% \mathrm{~K}_{2} \mathrm{O}\right)$ and/or Korn-Kali $\left(40 \% \mathrm{~K}_{2} \mathrm{O}, 6 \% \mathrm{MgO}, 4 \% \mathrm{Na}_{2} \mathrm{O}\right.$, and $\left.12 \% \mathrm{SO}_{3}\right)$ fertilizers were applied before WOSR sowing. Magnesium and sulfur were applied in the form of Korn-Kali (Kieserite) and/or Epsom salt, according to the schedule of the experiment, i.e., two weeks before OSR sowing (Autumn) and/or before spring regrowth, respectively. Epsom salt was applied at BBCH 30 . The size of an individual plot was $54 \mathrm{~m}^{2}$. Winter triticale was a forecrop for WOSR. The Chagall variety of WOSR is a hybrid characterized by a high yielding potential for medium fertile soils. It was sown at the rate of $3.0 \mathrm{~kg} \mathrm{ha}^{-1}$ at the end of August and harvested by a plot combine harvester at the end of July, from an area of $15 \mathrm{~m}^{2}$. The seeds were harvested at maturity when the moisture content was $8 \%$ dry weight.

Table 2. Experimental design: composition, rates and timing of fertilization treatments.

\begin{tabular}{|c|c|c|c|c|c|c|c|c|c|}
\hline \multirow{3}{*}{ Code of the Treatment } & \multicolumn{2}{|c|}{$\mathbf{N}$} & $\mathrm{P}_{2} \mathrm{O}_{5}{ }^{1}$ & \multicolumn{2}{|c|}{$\mathrm{K}_{2} \mathrm{O}^{2}$} & \multicolumn{2}{|c|}{ Mg } & \multicolumn{2}{|c|}{ S } \\
\hline & \multicolumn{9}{|c|}{ Time and Rate of Applied Fertilizer, $\mathrm{kg} \mathrm{ha}^{-1}$} \\
\hline & $A^{3}$ & $\mathrm{~S}^{4}$ & A & A & S & A & S & A & $\mathrm{S}$ \\
\hline $\mathrm{AC}$ & 0 & 0 & 0 & 0 & 0 & 0 & 0 & 0 & 0 \\
\hline NP & 27 & 187 & 69 & 0 & 0 & 0 & 0 & 0 & 0 \\
\hline NPK & 27 & 187 & 69 & 180 & 0 & 0 & 0 & 0 & 0 \\
\hline NPKMgS1 & 27 & 187 & 69 & 180 & 49.8 & 0 & 5.4 & 0 & 6.0 \\
\hline NPKMgS2 & 27 & 187 & 69 & 180 & 0 & 16.2 & 0 & 18.0 & 0 \\
\hline NPKMgS3 & 27 & 187 & 69 & 180 & 49.8 & 10.8 & 5.4 & 12.0 & 6.0 \\
\hline
\end{tabular}

\subsection{Source of Primary Data}

Plant material used for the determination of dry matter and measurement of nutrient concentrations was collected from an area of $1.0 \mathrm{~m}^{2}$. Plants were sampled at two cardinal growth stages: BBCH 61 (the beginning of flowering-10\% of flowers are present on the main stem) and BBCH 89 (maturity-nearly all pods are ripe, with dark, hard seeds). Plant samples were taken from the same sowing rows across a particular experimental block. At maturity, the harvested plant sample was partitioned into a subsample of seeds, and post-harvest residues (stem, fallen + remained leaves, and threshed pods). At BBCH 89, three of the yield's components were analyzed, i.e., the number of pods per $\mathrm{m}^{2}$ (pod density, $\mathrm{PD}$ ), the number of seeds per $\mathrm{m}^{2}$ (seed density, $\mathrm{SD}$ ), and the thousand-seed weight (TSW, g). Details of yield and yield components are shown in Table A1 and reported by Grzebisz et al. [13].

The nitrogen concentration in the plant samples was determined using a standard macro-Kjeldahl procedure. For mineral nutrients, the harvested plant sample was dried at $65^{\circ} \mathrm{C}$ and then mineralized at $550{ }^{\circ} \mathrm{C}$. The obtained ash was then dissolved in $33 \% \mathrm{HNO}_{3}$. Phosphorus concentration was measured 
by the vanadium-molybdenum method using a Specord 2XX/40 (Analytik Jena, Jena, Germany), at a wavelength of $436 \mathrm{~nm}$. The concentration of $\mathrm{K}, \mathrm{Mg}, \mathrm{Ca}, \mathrm{Zn}, \mathrm{Mn}$, and $\mathrm{Cu}$ was determined using atomic absorption spectrometry-flame type. The results were expressed on a dry matter basis. The amount of a given nutrient accumulated in plant parts was calculated by multiplying its concentration and the dry weight of a respective plant part weight.

\subsection{Calculated Parameters}

Based on the amount of a given nutrient accumulation $\left(\mathrm{N}_{\mathrm{a}}\right)$ in the respective parts of WOSR plants at the onset of flowering ( $\mathrm{BBCH}$ 61) and at physiological maturity $(\mathrm{BBCH} 89)$, four indices have been calculated:

Nutrient remobilization quota, NRQ, $\mathrm{kg} \mathrm{ha}^{-1}$ :

$$
\mathrm{NRQ}=\mathrm{N}_{\mathrm{a} 61}-\mathrm{N}_{\mathrm{a} 89 \mathrm{hr}}
$$

Post-flowering nutrient uptake by the oilseed rape canopy during SFP, $\mathrm{PN}_{\mathrm{a}} \mathrm{U}, \mathrm{kg} \mathrm{ha}^{-1}$ :

$$
\mathrm{PN}_{\mathrm{a}} \mathrm{U}=\mathrm{N}_{\mathrm{a} 89}-\mathrm{N}_{\mathrm{a} 61}
$$

Nutrient harvest index, NHI, \%

$$
\mathrm{NHI}=\left(\mathrm{N}_{\mathrm{as}} / \mathrm{N}_{\mathrm{a} 89}\right) \times 100 \%
$$

Nutrient reutilization coefficient, NRC, \%

$$
\mathrm{NRC}=\left(\mathrm{NRQ} / \mathrm{N}_{\mathrm{as}}\right) \times 100 \%
$$

where: $\mathrm{N}_{\mathrm{a} 61}$ and $\mathrm{N}_{\mathrm{a} 89}$ are the total nutrient amounts in the WOSR canopy at BBCH 61 and BBCH 89 in $\mathrm{kg} \mathrm{ha}^{-1}$ for macronutrients, and $\mathrm{g} \mathrm{ha}{ }^{-1}$ for micronutrients; $\mathrm{N}_{\mathrm{sa}}, \mathrm{N}_{\mathrm{a} 89 \mathrm{hr}}$ is the amount of any given nutrient in the WOSR seeds, and vegetative organs (fallen leaves + stem + threshed pods, respectively, $\mathrm{kg} \mathrm{ha}^{-1}$, for macronutrients and $\mathrm{g} \mathrm{ha}^{-1}$ for micronutrients).

\subsection{Statistical Analyses}

The data were subjected to a conventional analysis of variance using STATISTICA ${ }^{\circledR} 10$ (StatSoft, Krakow, Poland). The differences between treatments were evaluated with Tukey's test. In the second step, a principal component analysis (PCA) was used to illustrate the dependence between the amounts of nutrient accumulation in a particular WOSR part and yield, and its components. In the third step of the diagnostic procedure, stepwise regression was applied to define an optimal set of nutrient-variables for a given crop component characteristic. In the computational procedure, a consecutive variable was removed from the multiple linear regressions in a step-by-step manner. The best regression model was chosen based on the highest F-value for the model and the significance of all independent variables.

\section{Results}

\subsection{Onset of Flowering}

The composition of fertilizers and the amount of applied nutrients significantly affected nutrient uptake by WOSR at the beginning of flowering in consecutive growth seasons (Table 3). The nutrient uptake showed sensitivity to the interaction of weather conditions and fertilization treatments. It is best expressed through values of a coefficient of variation $(\mathrm{CV}, \%)$, which increased in the order:

$$
\mathrm{Mg}(26)<\mathrm{Ca}(32)<\mathrm{Zn}(41)=\mathrm{N}(41) \leq \mathrm{Mn}(42) \leq \mathrm{P}(43)<\mathrm{K}(46)<\mathrm{Cu}(51) .
$$


Table 3. Nutrient accumulation in oilseed rape at the beginning of flowering.

\begin{tabular}{|c|c|c|c|c|c|c|c|c|c|}
\hline \multirow{3}{*}{$\begin{array}{l}\text { Year } \\
\text { (Y) }\end{array}$} & \multirow{3}{*}{$\begin{array}{l}\text { Factor } \\
\text { (F) }\end{array}$} & \multicolumn{8}{|c|}{ Nutrients } \\
\hline & & $\mathbf{N}$ & $\mathbf{P}$ & $\mathbf{K}$ & $\mathrm{Mg}$ & $\mathrm{Ca}$ & Zn & Mn & $\mathrm{Cu}$ \\
\hline & & \multicolumn{5}{|c|}{$\mathrm{kg} \mathrm{ha}^{-1}$} & \multicolumn{3}{|c|}{$\mathrm{g} \mathrm{ha}^{-1}$} \\
\hline \multirow[t]{8}{*}{2008} & AC & $59.8 \mathrm{a}$ & $16.2 \mathrm{a}$ & 91.9 & 11.3a & $40.8 \mathrm{a}$ & $61.8 \mathrm{a}$ & $88.1 \mathrm{a}$ & 13.3a \\
\hline & NP. & $192.1 \mathrm{c}$ & $37.7 \mathrm{c}$ & $238.0 \mathrm{~d}$ & $24.6 \mathrm{c}$ & $89.6 \mathrm{~b}$ & $190.1 c$ & $226.3 \mathrm{~d}$ & $29.8 \mathrm{~b}$ \\
\hline & NPK & $146.4 \mathrm{bc}$ & $28.2 \mathrm{~b}$ & $172.0 \mathrm{~b}$ & $18.4 \mathrm{~b}$ & $67.0 \mathrm{~b}$ & $133.8 \mathrm{~b}$ & $150.2 b$ & $22.8 \mathrm{~b}$ \\
\hline & NPKMgS1 & $140.2 \mathrm{bc}$ & $29.1 b$ & $218.1 \mathrm{~cd}$ & $18.3 b$ & $71.5 \mathrm{~b}$ & $172.0 \mathrm{bc}$ & $154.6 \mathrm{bc}$ & $22.8 \mathrm{~b}$ \\
\hline & NPKMgS2 & $186.7 \mathrm{bc}$ & $32.7 \mathrm{bc}$ & $194.0 \mathrm{bc}$ & $24.1 \mathrm{bc}$ & $79.2 \mathrm{~b}$ & $164.3 \mathrm{bc}$ & $202.2 \mathrm{~cd}$ & $25.9 \mathrm{~b}$ \\
\hline & NPKMgS3 & $141.0 \mathrm{~b}$ & $28.7 \mathrm{~b}$ & $173.2 \mathrm{~b}$ & $17.6 \mathrm{~b}$ & $66.9 \mathrm{~b}$ & $138.7 \mathrm{~b}$ & $149.4 \mathrm{~b}$ & $21.9 \mathrm{~b}$ \\
\hline & $F$-value & $17.3^{* * *}$ & $16.4^{* * *}$ & $30.4^{* * *}$ & $17.6^{* * *}$ & $8.2^{* * *}$ & $21.8^{* * *}$ & $19.8^{* * *}$ & $9.4^{* * *}$ \\
\hline & SE & 11.4 & 1.75 & 9.19 & 1.16 & 5.70 & 9.68 & 10.8 & 1.78 \\
\hline \multirow[t]{8}{*}{2009} & $\mathrm{AC}$ & $132.2 \mathrm{a}$ & $10.6 a$ & $253.5 \mathrm{a}$ & $12.2 \mathrm{a}$ & $55.7 \mathrm{a}$ & $133.8 \mathrm{a}$ & $142.6 \mathrm{a}$ & $24.2 \mathrm{a}$ \\
\hline & NP. & $265.5 b$ & $21.4 b c$ & 309.9ab & $19.5 \mathrm{ab}$ & $80.9 \mathrm{ab}$ & $314.9 \mathrm{~b}$ & $350.0 \mathrm{~b}$ & $48.7 \mathrm{ab}$ \\
\hline & NPK & $322.1 \mathrm{bc}$ & $28.7 \mathrm{c}$ & $473.6 \mathrm{~cd}$ & $27.6 c$ & $115.1 \mathrm{~b}$ & $307.4 \mathrm{~b}$ & $325.2 b$ & $59.8 b$ \\
\hline & NPKMgS1 & $359.7 \mathrm{c}$ & $23.5 b c$ & $556.9 \mathrm{~d}$ & $21.3 \mathrm{bc}$ & $110.2 \mathrm{ab}$ & $395.9 b$ & $503.7 \mathrm{c}$ & $62.7 b$ \\
\hline & NPKMgS2 & $300.0 \mathrm{bc}$ & $23.6 \mathrm{bc}$ & $381.7 \mathrm{bc}$ & $17.2 \mathrm{bc}$ & $92.3 \mathrm{ab}$ & $294.0 \mathrm{~b}$ & $331.2 \mathrm{~b}$ & 47.1ab \\
\hline & NPKMgS3 & $332.7 \mathrm{bc}$ & $19.7 \mathrm{~b}$ & $476.5 \mathrm{~cd}$ & $22.0 \mathrm{bc}$ & $113.4 \mathrm{ab}$ & $325.7 b$ & $343.6 \mathrm{~b}$ & $58.1 \mathrm{~b}$ \\
\hline & $F$-value & $22.2^{* * *}$ & $9.3^{* * *}$ & $21.9^{* * *}$ & $9.9 * * *$ & $3.2 * * *$ & $7.8^{* * *}$ & $12.7^{* * *}$ & $4.6^{* *}$ \\
\hline & SE & 16.9 & 1.93 & 24.5 & 1.61 & 12.8 & 30.4 & 31.5 & 6.42 \\
\hline \multirow[t]{8}{*}{2010} & $\mathrm{AC}$ & $137.9 a$ & $42.1 \mathrm{a}$ & $162.6 \mathrm{a}$ & 13.7 & $106.9 \mathrm{ab}$ & 132.8 & $176.3 a$ & 20.8 \\
\hline & NP. & $149.7 \mathrm{a}$ & $42.2 a$ & $224.9 \mathrm{ab}$ & 14.0 & $101.0 \mathrm{ab}$ & 216.8 & $257.5 \mathrm{ab}$ & 21.1 \\
\hline & NPK & $148.6 a$ & $49.3 \mathrm{ab}$ & $196.8 \mathrm{ab}$ & 15.8 & $161.4 \mathrm{c}$ & 182.9 & $206.9 \mathrm{ab}$ & 22.0 \\
\hline & NPKMgS1 & $240.2 b$ & $50.7 \mathrm{ab}$ & $231.5 \mathrm{ab}$ & 13.2 & $104.7 \mathrm{ab}$ & 190.3 & $335.0 \mathrm{~b}$ & 23.2 \\
\hline & NPKMgS2 & $235.5 \mathrm{~b}$ & $63.0 \mathrm{~b}$ & $245.1 \mathrm{~b}$ & 14.0 & $69.3 a$ & 214.7 & $341.8 \mathrm{~b}$ & 20.5 \\
\hline & NPKMgS3 & $191.6 \mathrm{ab}$ & $54.8 \mathrm{ab}$ & $266.8 \mathrm{~b}$ & 16.4 & $127.2 \mathrm{bc}$ & 201.8 & $273.2 \mathrm{ab}$ & 20.1 \\
\hline & $F$-value & $7.2^{* * *}$ & $4.4^{* *}$ & $5.5^{* *}$ & 0.8 & $8.8^{* * *}$ & 2.3 & $4.0^{*}$ & 2.0 \\
\hline & SE & 17.0 & 3.80 & 15.7 & 1.39 & 10.3 & 20.3 & 33.5 & 4.49 \\
\hline $\mathrm{Y} \times \mathrm{F}$ & $F$-value & $7.5^{* * *}$ & $4.0^{* * *}$ & $12.0 * * *$ & $6.9 * * *$ & $4.5^{* * *}$ & $2.6^{*}$ & $4.2 * * *$ & $2.6^{*}$ \\
\hline
\end{tabular}

The coefficient of variation for seed yield ( $\mathrm{Y}$ ) was $24 \%$, whereas for seed density (SD), it reached $36 \%$, increasing up to $46 \%$ for pod density (PD), but only $13 \%$ for the thousand seed weight (TSW) (Table A1). The most stable Mg accumulation was recorded in 2010, in which it was both low and did not show any response to fertilization treatments. In both previous years $(2008,2009)$, the applied fertilizers resulted in a significant increase in the Mg uptake by plants, irrespective of the treatment. In 2008, its highest amount was recorded in plants fertilized only with NP and NPKMgS2, but in 2009, it was an attribute of the NPK treatment.

The effect of applied fertilizers on K and N uptake by WOSR at the onset of flowering was modified by the weather. The high year-to-year variability in $\mathrm{K}$ uptake was due to its extremal accumulation in 2009. It was almost 2-fold higher than other years. Three different patterns of $\mathrm{K}$ uptake response to the progressively applied nutrients were observed. In the first step, irrespective of the growth season, NP application significantly raised K uptake, as compared to the absolute control (AC). In 2008, plants fertilized with NP accumulated the highest amount of K. In 2009, a further two steps were observed, respecting $\mathrm{K}$ accumulation in the WOSR canopy. The 2nd step was revealed in the response to NPK application with respect to NP, and the 3rd on the plot fertilized with NPKMgS2, in respect to NPK. The same pattern was observed in 2010, but the highest $\mathrm{K}$ uptake was recorded on the NPKMgS3 plot, which received MgS both in autumn, before OSR sowing and in spring, before the start of vegetation. Nitrogen showed a very similar pattern to that as observed for K. In addition, the N:K ratio were almost constant, ranging, averaged over fertilization treatments, from 0.70:1 in 2009 to 0.82:1 in 2010. Patterns of micronutrient uptake were very close to those observed for K, reaching maxima on plots with MgS.

Principal component analysis (PCA) clearly revealed a distinct impact of particular nutrients on the strength of relationships between the nutrient uptake and yield components of WOSR, and its final yield. The PCs with eigenvalues greater than 1.0 were used as a primary criterion to determine the number of PCs. The first three principal components (PCs) accounted for $92.17 \%$ of the total 
variance in the data (Table A2). However, only the variables with scores on PCs over $0.70\left(R^{2}>0.50\right)$ were taken into consideration. PC1 and PC2 contributed to $50.92 \%$ and $31.78 \%$ of the total variance, respectively. Overall, 7 of the 12 variables had loadings on PC1, fulfilling the chosen criteria. The highest, and at the same time positive loadings, were recorded in descending order $(r)$ for $\mathrm{Cu}, \mathrm{K}, \mathrm{N}, \mathrm{Zn}, \mathrm{Mg}$, $\mathrm{Mn}$, and PD. The loading for yield (Y) was positive, but low (Table A2). The required criteria for PC2 were reached for Ca, TSW (positive), and SD (negative). The studied variable weight was evaluated by the eigenvector, which varies between -1 to +1 . The eigenvectors for the examined variables were broadly scattered on the two first PCA axes. The closest to the absolute of 1 were Mg and PD (Figure 1a). However, as results from the scatter plot for PC1 and PC3 show, PD revealed the closest distance to the other set of nutrients (Figure $1 \mathrm{~b}$ ). The distance of $\mathrm{Mg}$ to $\mathrm{SD}$, and to $\mathrm{Y}$, as seen in the results from Figure $1 \mathrm{~b}$, was the closest among the studied nutrients. These observations were corroborated by respective stepwise regression models (Table A4, Equations (A1)-(A3)). Mg uptake by WOSR plants at the onset of flowering was a decisive nutritional factor for SD expression, and consequently, for seed yield. PD was limited by a shortage of N. The development of SD was limited by an excess of Ca, which was recorded in 2009 and 2010, as compared to 2008. TSW, as shown in Figure 1a, was close to absolute of 1 , as seen on the PC2 axe, being negatively correlated with SD, but positively with $\mathrm{P}$ and $\mathrm{Ca}$ (Table A4, Equation (A4)).

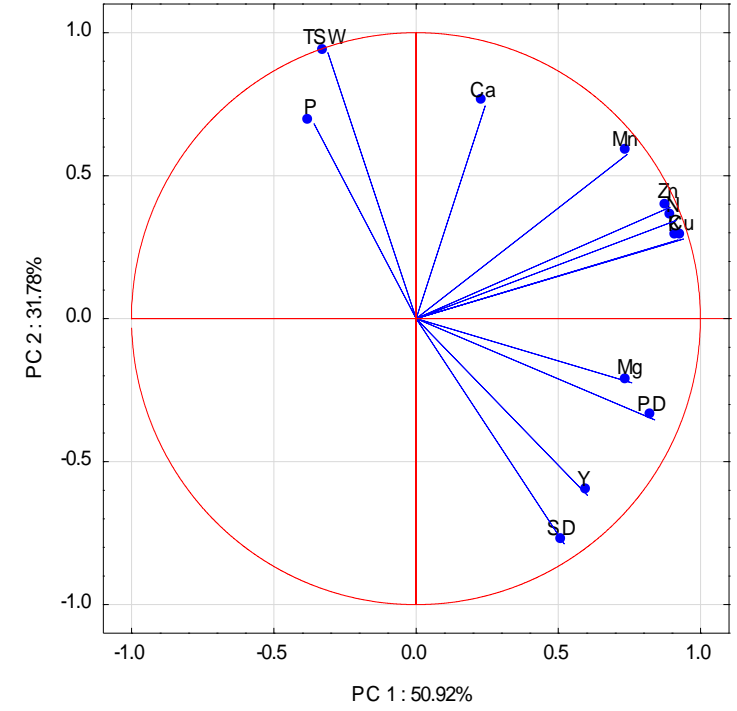

(a)

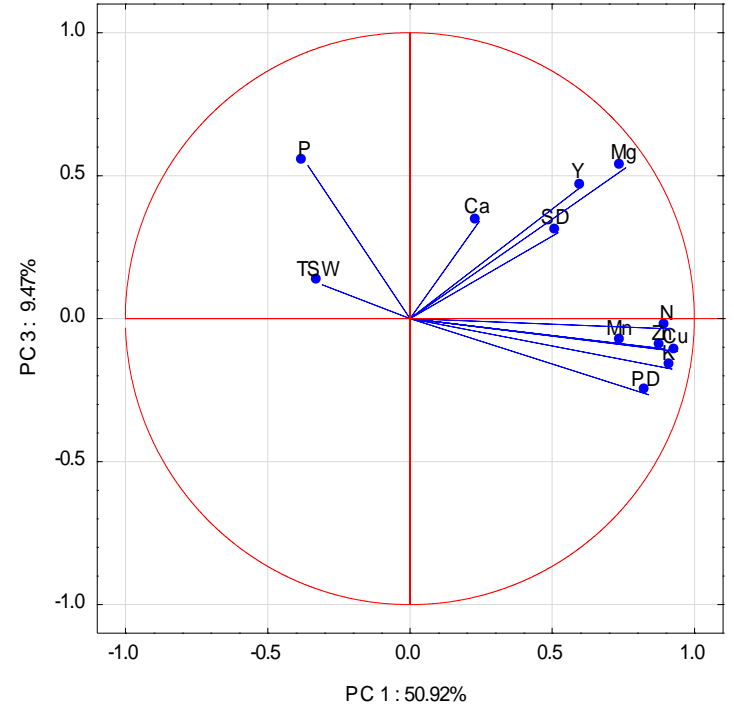

(b)

Figure 1. (a) Score plot of winter oilseed rape (WOSR) components and nutrient accumulated in WOSR biomass at flowering in PC1 and PC2 axes. (b) Score plot of WOSR components and nutrient accumulated in WOSR biomass at flowering in PC1 and PC3 axes. Y-Yield, SD-Seed Density, PD—Pod Density, TSW—Thousand Seed Weight, N, P, K, Mg, Ca, Mn, Zn, Cu—nutrients.

\subsection{Physiological Maturity—Seeds}

The amount of nutrients accumulated in WOSR seeds was significantly affected by the applied fertilizers in particular years of study (Table 4). The order of nutrients, with respect to their seasonal variability, as indicated by a coefficient of variability $(\mathrm{CV}, \%)$, was as follows:

$$
\mathrm{Ca}(16) \leq \mathrm{Cu}(18)<\mathrm{N}(24) \leq \mathrm{K}(25) \leq \mathrm{P}(26) \leq \mathrm{Mg}(28)<\mathrm{Mn}(37)<\mathrm{Zn}(43) .
$$


Table 4. Nutrient accumulation in WOSR seeds.

\begin{tabular}{|c|c|c|c|c|c|c|c|c|c|}
\hline \multirow{2}{*}{$\begin{array}{c}\text { Year } \\
(Y)\end{array}$} & \multirow{2}{*}{$\begin{array}{c}\text { Factor } \\
\text { (F) }\end{array}$} & \multicolumn{5}{|c|}{ Macronutrients, $\mathrm{kg} \mathrm{ha}^{-1}$} & \multicolumn{3}{|c|}{ Micronutrients, $\mathrm{g} \mathrm{ha}^{-1}$} \\
\hline & & $\mathbf{N}$ & $\mathbf{P}$ & $\mathbf{K}$ & Mg & $\mathrm{Ca}$ & Zn & Mn & $\mathrm{Cu}$ \\
\hline \multirow[t]{8}{*}{2008} & $\mathrm{AC}$ & $83.1 \mathrm{a}$ & $27.4 \mathrm{a}$ & $28.5 a$ & $9.6 \mathrm{a}$ & $10.5 a$ & $94.3 \mathrm{a}$ & $92.7 \mathrm{a}$ & $11.4 \mathrm{a}$ \\
\hline & NP. & $136.8 \mathrm{~b}$ & $35.6 \mathrm{ab}$ & $39.7 \mathrm{ab}$ & $12.7 \mathrm{ab}$ & $13.5 \mathrm{ab}$ & $129.1 b$ & $130.2 \mathrm{ab}$ & $14.6 \mathrm{ab}$ \\
\hline & NPK & $156.7 \mathrm{ab}$ & $40.3 b c$ & $44.3 \mathrm{bc}$ & $14.2 \mathrm{~b}$ & $15.5 b c$ & $157.6 \mathrm{bc}$ & $149.5 b c$ & $16.3 b c$ \\
\hline & NPKMgS1 & $144.9 \mathrm{ab}$ & $36.4 \mathrm{ab}$ & $42.1 \mathrm{~b}$ & $13.1 \mathrm{ab}$ & $14.4 \mathrm{~b}$ & $149.6 \mathrm{bc}$ & $150.5 b c$ & $15.0 \mathrm{ab}$ \\
\hline & NPKMgS2 & $190.4 b$ & $46.9 \mathrm{c}$ & $54.5 \mathrm{c}$ & $16.2 b$ & $17.9 \mathrm{c}$ & $176.8 \mathrm{c}$ & 178.1c & $18.8 \mathrm{c}$ \\
\hline & NPKMgS3 & $154.3 \mathrm{ab}$ & $41.8 \mathrm{bc}$ & $47.8 \mathrm{bc}$ & $14.7 \mathrm{ab}$ & $15.4 \mathrm{bc}$ & $161.8 \mathrm{bc}$ & $167.9 \mathrm{bc}$ & $16.7 \mathrm{bc}$ \\
\hline & $F$-value & $12.2^{* * *}$ & $9.5^{* * *}$ & $11.5^{* * *}$ & $7.1^{* * *}$ & $10.7^{* * *}$ & $16.1^{* * *}$ & $9.8^{* * *}$ & $9.6^{* * *}$ \\
\hline & SE & 10.1 & 2.15 & 2.57 & 0.85 & 0.76 & 7.32 & 9.71 & 0.81 \\
\hline \multirow[t]{8}{*}{2009} & AC & $92.9 a$ & $16.8 \mathrm{a}$ & $23.0 \mathrm{a}$ & $8.7 a$ & $11.2 \mathrm{a}$ & $211.5 \mathrm{a}$ & $137.7 \mathrm{a}$ & $12.0 \mathrm{a}$ \\
\hline & NP. & $143.0 \mathrm{~b}$ & 23.3ab & $31.4 \mathrm{ab}$ & $11.8 \mathrm{ab}$ & $14.2 \mathrm{ab}$ & $269.8 \mathrm{ab}$ & $194.4 \mathrm{ab}$ & $16.3 \mathrm{ab}$ \\
\hline & NPK & $186.4 \mathrm{~b}$ & $28.7 \mathrm{~b}$ & $39.5 b$ & $14.4 \mathrm{~b}$ & $17.5 \mathrm{~b}$ & $326.4 \mathrm{~b}$ & $252.7 \mathrm{~b}$ & $19.7 \mathrm{~b}$ \\
\hline & NPKMgS1 & $163.8 \mathrm{~b}$ & $26.6 \mathrm{~b}$ & $36.7 \mathrm{~b}$ & $13.9 \mathrm{~b}$ & $16.0 \mathrm{~b}$ & $325.8 \mathrm{~b}$ & $234.0 \mathrm{~b}$ & $18.8 \mathrm{~b}$ \\
\hline & NPKMgS2 & $158.3 b$ & $26.5 b$ & $35.5 b$ & $13.3 b$ & $16.6 \mathrm{~b}$ & 252.0ab & $214.6 \mathrm{ab}$ & $17.9 \mathrm{~b}$ \\
\hline & NPKMgS3 & $181.1 \mathrm{~b}$ & $27.9 \mathrm{~b}$ & $40.1 \mathrm{~b}$ & $14.6 \mathrm{~b}$ & $17.0 \mathrm{~b}$ & $313.9 \mathrm{ab}$ & $267.8 b$ & $19.7 b$ \\
\hline & $F$-value & $9.3^{* * *}$ & $6.8^{* * *}$ & $8.6^{* * *}$ & $6.9^{* * *}$ & $6.7^{* *}$ & $3.6^{*}$ & $6.1^{* *}$ & $6.9^{* * *}$ \\
\hline & SE & 11.1 & 1.69 & 18.4 & 0.85 & 0.91 & 24.6 & 19.0 & 1.11 \\
\hline \multirow[t]{8}{*}{2010} & $\mathrm{AC}$ & $78.1 \mathrm{a}$ & $25.6 \mathrm{a}$ & $19.6 \mathrm{a}$ & 5.2 & 9.9 & 73.1a & $63.1 \mathrm{a}$ & 10.3 \\
\hline & NP. & $114.9 \mathrm{ab}$ & $37.0 \mathrm{ab}$ & $26.5 \mathrm{ab}$ & 8.3 & 16.8 & $136.0 \mathrm{~b}$ & $120.6 \mathrm{~b}$ & 18.5 \\
\hline & NPK & $120.1 \mathrm{ab}$ & $43.2 b$ & $34.3 b$ & 8.0 & 15.4 & $135.7 \mathrm{~b}$ & $112.1 \mathrm{~b}$ & 15.9 \\
\hline & NPKMgS1 & $124.8 b$ & $39.3 \mathrm{ab}$ & $29.6 \mathrm{ab}$ & 8.9 & 17.6 & $150.8 b$ & $119.3 b$ & 19.6 \\
\hline & NPKMgS2 & $127.2 \mathrm{~b}$ & $46.1 \mathrm{~b}$ & $33.5 b$ & 8.4 & 16.4 & $152.3 b$ & $123.1 \mathrm{~b}$ & 19.9 \\
\hline & NPKMgS3 & $119.7 \mathrm{ab}$ & $42.4 \mathrm{~b}$ & $31.5 \mathrm{ab}$ & 7.7 & 16.7 & $119.2 \mathrm{ab}$ & $100.6 \mathrm{ab}$ & 17.1 \\
\hline & $F$-value & $3.4^{*}$ & $3.7 *$ & $3.3 *$ & 1.7 & 1.6 & $5.1^{* *}$ & $4.5^{* *}$ & 1.8 \\
\hline & SE & 8.81 & 3.41 & 2.78 & 0.91 & 2.00 & 11.8 & 9.64 & 2.37 \\
\hline $\mathrm{Y} \times \mathrm{F}$ & $F$-value & $2.1^{*}$ & 0.8 & 1.4 & 1.4 & 0.8 & 2.0 & $2.4 *$ & 1.1 \\
\hline
\end{tabular}

${ }_{* * *}, * *, *$ significant at $p<0.001 ;<0.01 ;<0.05$, respectively; SE-Standard error; ${ }^{\text {a }}$ within a year, means within a column, followed by the same letter, indicates a lack of significant difference between the treatments.

Only Zn showed a higher variability during the seed filling period (SFP), as compared to the onset of flowering. The greatest decline was recorded for $\mathrm{Cu}(-33 \%), \mathrm{K}(-21 \%), \mathrm{N}(-17 \%)$, and $\mathrm{Ca}(-16 \%)$. A significant response of the studied nutrients to the interaction of year and fertilization treatments was recorded only for $\mathrm{N}$ and $\mathrm{Mn}$. Irrespective of the course of weather, the lowest amount of $\mathrm{N}$ in seeds was found in the AC plot. The highest N accumulation was recorded in 2008 on the NPKMgS2 plot, where it increased by $21.5 \%$, as compared to the NPK one. In 2010, a positive impact of MgS treatments on N accumulation with respect to NPK was also observed. In 2009, the highest N accumulation was recorded on the NPK plot. The accumulation of Mn showed a very similar response to fertilization treatments in consecutive growth seasons to that observed for $\mathrm{N}$. The same trends were observed for $\mathrm{K}$, $\mathrm{Mg}$, and to a minor extent, for $\mathrm{Ca}, \mathrm{Cu}$, and $\mathrm{Zn}$. It is necessary to stress that amounts of $\mathrm{K}$ and $\mathrm{Mg}$ in seeds showed the same trends as observed for seed yield (Table A1).

The first three principal components (PCs) with an eigenvalue $\geq 1.0$ accounted for $97.69 \%$. The criterion of variable loading on PCs over 0.70 was fulfilled only for PC1 and PC2. PC1 was significantly correlated with 8 of 12 variables. The highest, and positive loadings were recorded for $\mathrm{N}$, Mg, Mn, K, Zn, Mn, Y, SD, and TSW (Table A2). P and Ca had high, but negative loading on PC2. The eigenvectors for the examined variables were grouped on the first two PCA axes (Figure 2a). The closest to the absolute of 1 were $\mathrm{Y}, \mathrm{Mg}$ and $\mathrm{N}$, which were positively correlated with PC1. A clearer distribution of eigenvectors is shown on the PC1 and PC 3 scatter plot (Figure 2b). The closest distance of $\mathrm{SD}$ and $\mathrm{Y}$ to nutrients was found for $\mathrm{K}$ and $\mathrm{Mg}$. These dependences were corroborated by the stepwise regression analysis (Table A4, Equations (A5)-(A8)). In Y and SD models, the key nutritional factor was $\mathrm{Mg}$. SD was limited by a shortage of $\mathrm{Mg}$, and by an excessive accumulation of $\mathrm{Mn}$, and $\mathrm{Cu}$. An extreme amount of $\mathrm{Mn}$, with respect to the high yielding 2008, was recorded in 2009, and for $\mathrm{Cu}$ in 2010. As shown in Table A4, Equation (A5), WOSR yield was governed by the simultaneously occurring shortages of Mg and $\mathrm{K}$. TSW showed a positive response to $\mathrm{N}$, but the negative sign for $\mathrm{Mg}$ indicates its excess (Figure 2a,b). 


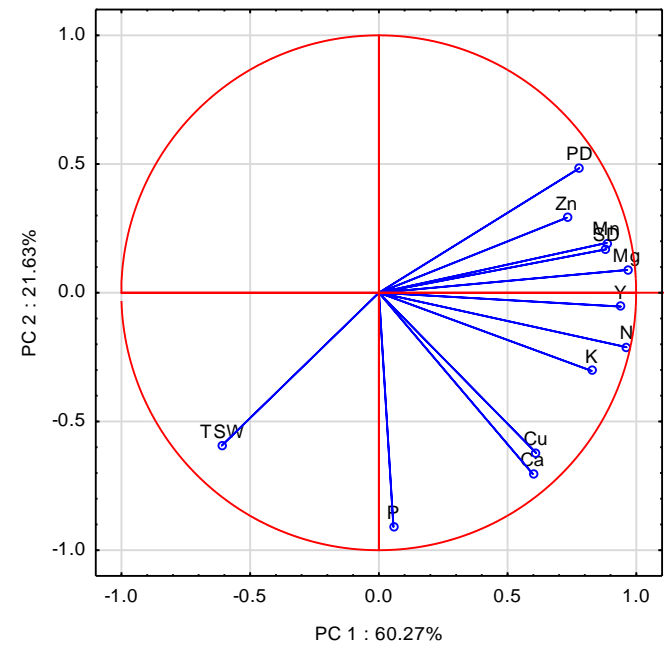

(a)

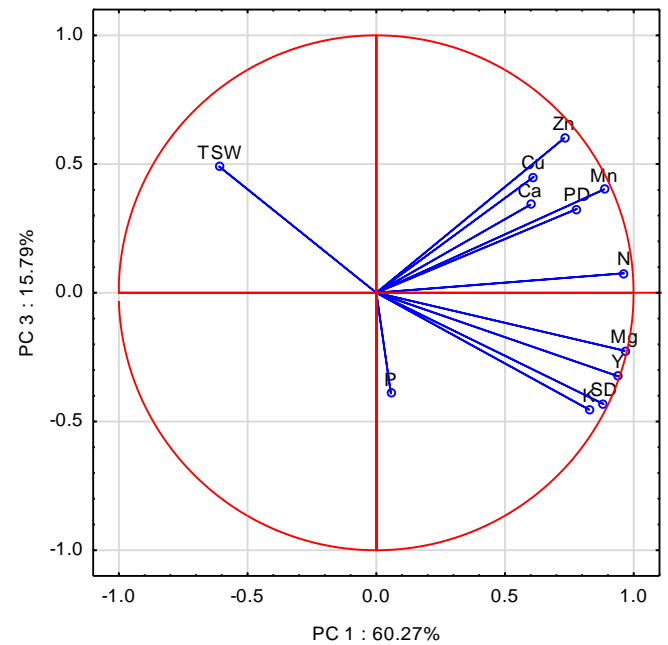

(b)

Figure 2. (a) Score plot of WOSR components and nutrient accumulated in WOSR seeds in PC1 and PC2 axes. (b) Score plot of WOSR components and nutrient accumulated in WOSR seeds in PC1 and PC3 axes. Y-Yield, SD—Seed Density, PD—Pod Density, TSW-Thousand Seed Weight, N, P, K, $\mathrm{Mg}, \mathrm{Ca}, \mathrm{Mn}, \mathrm{Zn}, \mathrm{Cu}-$ nutrients.

\subsection{Physiological Maturity—Post-Harvest Residues}

Nutrients accumulated in post-harvest residues showed, with the exception of $\mathrm{P}$ and $\mathrm{Zn}$, significant responses to the interaction of weather and fertilization treatments (Table 5). The general pattern of $\mathrm{N}$ in consecutive years of study was very similar to that found for seeds. However, in 2008, the highest $\mathrm{N}$ accumulation was recorded for NP, whereas in 2010, it was for NPK. As a rule, a much higher amount of $\mathrm{N}$ was found in 2010, as compared to both previous years. The amount of $\mathrm{K}$ in post-harvest residues showed a declining trend in consecutive years of study, being in accordance with the pattern recorded for seed yield (Table A1). A reverse annual pattern was observed for Mn, whose accumulation was the highest in 2010. Zinc followed the pattern described for N, but differences between the years were stronger. The amount of $\mathrm{P}$ in post-harvest residues only depended on fertilization treatments. Averaged over years, the highest $\mathrm{P}$ accumulation was attributed to the NPK plot, followed by treatments fertilized with $\mathrm{MgS}$. Amounts of $\mathrm{Mg}, \mathrm{Ca}$, and $\mathrm{Cu}$ accumulated in post-harvest residues were the lowest in 2009, showing a high resemblance to the pattern observed for $P$.

The first three principal components (PCs) with an eigenvalue $\geq 1.0$ accounted for $91.78 \%$ of the total variance in the data (Table 2A). The set of variables with scores on PC1 higher than 0.70 comprised 5 of 12 analyzed variables. The highest, and at the same time positive loadings on PC1 were recorded for K, $\mathrm{Mg}, \mathrm{Cu}, \mathrm{SD}$, and Y (Table A2). Ca had the highest and most positive score with PC2, but negative with Zn, and PD. Mn had a high, but negative loading on PC3. The eigenvectors for the examined variables were broadly scattered on the two first PCA axes (Figure 3). The closest to the absolute of 1 was $\mathrm{K}$, followed by $\mathrm{Y}$, and SD, which were positively correlated with PC1. The significant impact of $\mathrm{K}$, concomitant with $\mathrm{N}$ on yield, was corroborated by the stepwise regression analysis (Table A4, Equation (A9)). The model obtained clearly shows that yield was limited by a shortage of N and $\mathrm{K}$ in WOSR post-harvest residues. Potassium significantly affected PD and SD (Table A4, Equations (A10) and (A11)). The models obtained corroborate the importance of the amount of $\mathrm{K}$ in WOSR post-harvest residues for the development of both $\mathrm{PD}$, and subsequently the crucial yield component, i.e., SD. The negative impact of $\mathrm{Cu}$ became apparent, due to its high accumulation in straw in 2010, a year with the lowest yield. TSW showed an opposite location on the PC scatter plot, with respect to SD and $\mathrm{K}$. This relationship was fully corroborated by the stepwise regression analysis (Table A4, Equation (A12)). 
Table 5. Nutrient accumulation in WOSR post-harvest residues.

\begin{tabular}{|c|c|c|c|c|c|c|c|c|c|}
\hline \multirow{2}{*}{$\begin{array}{c}\text { Year } \\
(\mathrm{Y})\end{array}$} & \multirow{2}{*}{$\begin{array}{c}\text { Factor } \\
\text { (F) }\end{array}$} & \multicolumn{5}{|c|}{ Macronutrients, $\mathrm{kg} \mathrm{ha}^{-1}$} & \multicolumn{3}{|c|}{ Micronutrients, $\mathrm{g} \mathrm{ha}^{-1}$} \\
\hline & & $\mathbf{N}$ & $\mathbf{P}$ & $\mathbf{K}$ & Mg & $\mathrm{Ca}$ & $\mathrm{Zn}$ & Mn & $\mathrm{Cu}$ \\
\hline \multirow[t]{8}{*}{2008} & AC & $43.6 a$ & $13.6 \mathrm{a}$ & $244.6 a$ & 14.1 & $196.4 a$ & $50.5 a$ & $122.8 \mathrm{a}$ & $27.7 \mathrm{a}$ \\
\hline & NP. & $149.0 \mathrm{~d}$ & $15.5 \mathrm{ab}$ & $358.0 \mathrm{ab}$ & 16.7 & $203.8 \mathrm{a}$ & $73.2 \mathrm{ab}$ & $200.8 \mathrm{ab}$ & $34.2 \mathrm{ab}$ \\
\hline & NPK & $104.9 \mathrm{bcd}$ & $22.0 \mathrm{bc}$ & $420.7 \mathrm{bc}$ & 18.0 & $253.2 b$ & $77.3 \mathrm{ab}$ & $235.9 \mathrm{bc}$ & $41.8 \mathrm{bc}$ \\
\hline & NPKMgS1 & $80.9 \mathrm{ab}$ & 19.2abc & $423.9 b c$ & 16.3 & $221.9 a$ & 70.4ab & $230.5 b c$ & $36.8 \mathrm{ab}$ \\
\hline & NPKMgS2 & $131.7 \mathrm{~cd}$ & $23.2 \mathrm{c}$ & $573.6 \mathrm{c}$ & 22.5 & $329.6 c$ & $96.2 b$ & $283.9 \mathrm{~cd}$ & $48.8 \mathrm{c}$ \\
\hline & NPKMgS3 & $89.5^{\mathrm{abc}}$ & 19.4abc & $504.8 \mathrm{bc}$ & 19.4 & $261.7 \mathrm{bc}$ & $79.8 b$ & $328.3 \mathrm{~d}$ & $45.3 b c$ \\
\hline & $F$-value & $11.7^{* * *}$ & $6.3^{* *}$ & $10.8^{* * *}$ & 2.5 & $8.8^{* * *}$ & $5.3^{* *}$ & $15.0^{* * *}$ & $8.9^{* * *}$ \\
\hline & SE & 11.0 & 1.48 & 34.8 & 1.81 & 16.8 & 6.45 & 18.2 & 2.59 \\
\hline \multirow[t]{8}{*}{2009} & $\mathrm{AC}$ & $70.8 \mathrm{a}$ & $11.5 \mathrm{a}$ & $123.8 \mathrm{a}$ & $8.1 \mathrm{a}$ & 103.1 & $160.3 a$ & $156.2 \mathrm{a}$ & $20.4 a$ \\
\hline & NP. & $117.9 \mathrm{ab}$ & $18.4 \mathrm{a}$ & $270.2 b$ & $9.7 \mathrm{ab}$ & 125.7 & $204.9 \mathrm{ab}$ & $232.7 \mathrm{ab}$ & $31.0 \mathrm{ab}$ \\
\hline & NPK & $176.2 \mathrm{c}$ & 19.3a & $382.5 b$ & $15.1 \mathrm{~b}$ & 131.0 & $277.0 \mathrm{~b}$ & $332.7 \mathrm{~b}$ & $42.1 \mathrm{c}$ \\
\hline & NPKMgS1 & $147.2 \mathrm{bc}$ & $14.6 \mathrm{a}$ & $324.5 b$ & $9.5 \mathrm{a}$ & 116.3 & 231.0ab & $307.3 b$ & $30.3 a b$ \\
\hline & NPKMgS2 & $125.9 \mathrm{abc}$ & $19.0 \mathrm{a}$ & $291.3 b$ & $10.4 \mathrm{ab}$ & 131.7 & $224.0 \mathrm{ab}$ & $263.0 \mathrm{ab}$ & $31.7 \mathrm{bc}$ \\
\hline & NPKMgS3 & $145.5 b c$ & $19.1 \mathrm{a}$ & $366.8 b$ & $10.7 \mathrm{ab}$ & 150.5 & $254.3 b$ & $494.7 \mathrm{c}$ & $39.8 b c$ \\
\hline & $F$-value & $8.1^{* * *}$ & $3.4^{*}$ & $11.0^{* * *}$ & $3.9 *$ & 2.2 & $4.2 *$ & $18.1^{* * *}$ & $10.4^{* * *}$ \\
\hline & SE & 12.5 & 1.73 & 28.2 & 1.22 & 10.8 & 19.8 & 26.9 & 2.40 \\
\hline \multirow[t]{9}{*}{2010} & $\mathrm{AC}$ & $34.1 \mathrm{a}$ & $13.5 \mathrm{a}$ & 152.3 & $8.5 \mathrm{a}$ & $141.7 \mathrm{a}$ & $85.5 \mathrm{a}$ & $175.0 \mathrm{a}$ & 33.8 \\
\hline & NP. & 72.7ab & 17.1ab & 224.5 & 12.1ab & $212.9 \mathrm{bc}$ & $111.6 a$ & $415.1 \mathrm{bc}$ & 38.3 \\
\hline & NPK & $92.8 b$ & $25.1 b$ & 212.8 & $14.9 \mathrm{~b}$ & $237.0 \mathrm{c}$ & $158.4 \mathrm{a}$ & $511.5 \mathrm{c}$ & 36.9 \\
\hline & NPKMgS1 & $62.6 \mathrm{ab}$ & $21.0 \mathrm{ab}$ & 255.0 & $14.8 \mathrm{~b}$ & 203.0bc & $141.3 \mathrm{a}$ & $350.3 b$ & 37.0 \\
\hline & NPKMgS2 & $68.3 \mathrm{ab}$ & $15.7 \mathrm{ab}$ & 194.9 & $7.4 \mathrm{a}$ & $156.2 \mathrm{bc}$ & $99.9 a$ & $371.5 \mathrm{bc}$ & 34.2 \\
\hline & NPKMgS3 & $80.9 \mathrm{ab}$ & $19.3 \mathrm{ab}$ & 212.1 & $12.9 \mathrm{ab}$ & $199.2 \mathrm{bc}$ & $163.5 \mathrm{a}$ & $421.5 \mathrm{bc}$ & 31.5 \\
\hline & $F$-value & $3.0 *$ & $3.3 *$ & 2.0 & $6.2 * *$ & $7.9^{* * *}$ & $3.4 *$ & $11.5^{* * *}$ & 0.7 \\
\hline & SE & 11.4 & 2.29 & 24.0 & 1.28 & 12.8 & 17.6 & 33.2 & 3.04 \\
\hline & $F$-value & $3.4^{* *}$ & 1.8 & $4.6^{* * *}$ & $3.1^{* *}$ & $6.3^{* *}$ & 1.7 & $5.0 * * *$ & $4.2^{* *}$ \\
\hline
\end{tabular}

$\overline{* * *, * *, *}$ significant at $p<0.001 ;<0.01 ;<0.05$, respectively; SE-Standard error; ${ }^{\text {a }}$ within a year, means within a column followed by the same letter indicate a lack of significant difference between the treatments.

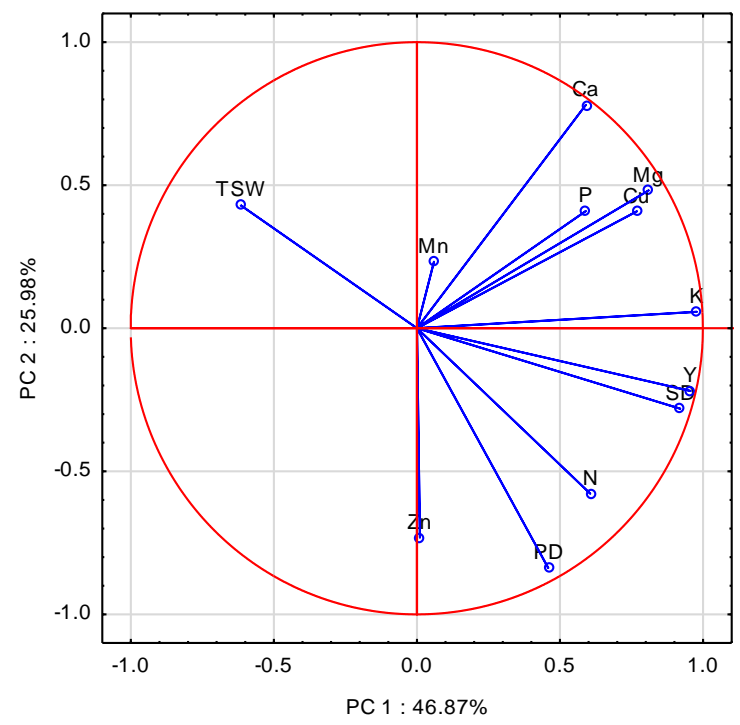

Figure 3. Score plot of WOSR components and nutrients accumulated in WOSR post-harvest residues in PC1 and PC2 axes. Y-Yield, SD-Seed Density, PD—Pod Density, TSW-Thousand Seed Weight, $\mathrm{N}, \mathrm{P}, \mathrm{K}, \mathrm{Mg}, \mathrm{Ca}, \mathrm{Mn}, \mathrm{Zn}, \mathrm{Cu}-$ nutrients.

\subsection{Physiological Maturity-Total Nutrient Accumulation}

The total amount of studied nutrients, except Zn, in the WOSR canopy at physiological maturity was significantly governed by applied fertilizers, being modified by the course of weather in consecutive years (Table 6). The highest $\mathrm{K}$ total accumulation was recorded in 2008 , a year with the highest seed yield. In this particular year, the highest amount of $\mathrm{K}$ was observed on the NPKMgS2 plot, where the full MgS dose had been applied before WOSR sowing. In 2009, the highest K accumulation was recorded on 
the NPK plot. In 2010, total K accumulation was much lower and any significant differences between treatments were recorded. A very similar pattern to that of $\mathrm{K}$ was recorded for $\mathrm{Mg}$, and a less strong one for $\mathrm{N}, \mathrm{Cu}, \mathrm{Ca}, \mathrm{P}$. The main reason for the differences between accumulation patterns for the last three nutrients was their higher uptake in 2010 with respect to 2009, but for N with respect to 2008. As shown in Table A5, the nutrient harvest index (NHI), reflecting the relative contribution of seeds in the total nutrient uptake by WORS at harvest, was nutrient specific. The highest NHI, exceeding 55\%, averaged over years, was recorded for $\mathrm{N}, \mathrm{P}$, and $\mathrm{Zn}$. The second group, for which $\mathrm{NHI}$ ranged between $30 \%$ to $50 \%$, included $\mathrm{Mg}$, Mn, and $\mathrm{Cu}$. The lowest $\mathrm{NHI}$, i.e., below 20\%, was recorded for $\mathrm{K}$ and Ca.

Table 6. Total nutrient content in oilseed rape at harvest.

\begin{tabular}{|c|c|c|c|c|c|c|c|c|c|}
\hline \multirow{2}{*}{$\begin{array}{c}\text { Year } \\
(\mathrm{Y})\end{array}$} & \multirow{2}{*}{$\begin{array}{c}\text { Factor } \\
\text { (F) }\end{array}$} & \multicolumn{5}{|c|}{ Macronutrients, $\mathrm{kg} \mathrm{ha}^{-1}$} & \multicolumn{3}{|c|}{ Micronutrients, $\mathrm{g} \mathrm{ha}^{-1}$} \\
\hline & & $\mathbf{N}$ & $\mathbf{P}$ & $\mathbf{K}$ & $\mathrm{Mg}$ & Ca & Zn & Mn & $\mathrm{Cu}$ \\
\hline \multirow[t]{8}{*}{2008} & $\mathrm{AC}$ & $126.8 \mathrm{a}$ & $41.0 \mathrm{a}$ & $273.2 \mathrm{a}$ & $23.7 \mathrm{a}$ & $206.9 a$ & $144.8 \mathrm{a}$ & $215.5 a$ & $39.1 \mathrm{a}$ \\
\hline & NP. & $285.8 \mathrm{bc}$ & $53.6 \mathrm{ab}$ & $397.7 \mathrm{ab}$ & $29.4 \mathrm{ab}$ & $217.3 a$ & $202.3 b$ & $331.0 \mathrm{~b}$ & $48.8 \mathrm{ab}$ \\
\hline & NPK & $261.6 \mathrm{bc}$ & $62.3 \mathrm{bc}$ & $465.0 \mathrm{~b}$ & $32.2 \mathrm{ab}$ & $268.7 a$ & $234.9 \mathrm{bc}$ & $385.4 b c$ & $58.1 b c$ \\
\hline & NPKMgS1 & $225.9 \mathrm{~b}$ & $55.6 \mathrm{abc}$ & $466.1 \mathrm{bc}$ & $29.4 a b$ & $236.3 a$ & $220.0 \mathrm{bc}$ & $381.0 \mathrm{bc}$ & $51.8 \mathrm{ab}$ \\
\hline & NPKMgS2 & $322.1 \mathrm{c}$ & $70.1 \mathrm{c}$ & $628.1 \mathrm{c}$ & $38.7 \mathrm{~b}$ & $347.5 b$ & $273.0 \mathrm{c}$ & $462.0 \mathrm{~cd}$ & $67.6 \mathrm{c}$ \\
\hline & NPKMgS3 & $243.8 \mathrm{~b}$ & $66.2 \mathrm{bc}$ & $552.6 \mathrm{bc}$ & 34.1ab & $277.1 \mathrm{ab}$ & $241.6 \mathrm{bc}$ & $496.3 \mathrm{~d}$ & $62.1 \mathrm{bc}$ \\
\hline & $F$-value & $16.3^{* * *}$ & $8.7^{* * *}$ & $11.6^{* * *}$ & $4.5^{* *}$ & $9.1^{* * *}$ & $12.0^{* * *}$ & $17.6^{* * *}$ & $10.8^{* * *}$ \\
\hline & SE & 16.5 & 3.55 & 36.1 & 2.38 & 17.1 & 12.6 & 23.8 & 3.09 \\
\hline \multirow[t]{8}{*}{2009} & $\mathrm{AC}$ & $173.2 \mathrm{a}$ & $28.3 a$ & $158.9 \mathrm{a}$ & $16.8 \mathrm{a}$ & 115.5 & $371.2 \mathrm{a}$ & $288.4 a$ & $32.7 \mathrm{a}$ \\
\hline & NP. & $260.9 \mathrm{ab}$ & $41.8 \mathrm{ab}$ & $301.6 a b$ & $21.6 a b$ & 140.0 & $474.8 \mathrm{ab}$ & 427.1ab & $47.3 \mathrm{ab}$ \\
\hline & NPK & $362.6 \mathrm{c}$ & $50.5 \mathrm{~b}$ & $422.0 \mathrm{~b}$ & $29.5 b$ & 148.5 & $603.4 \mathrm{~b}$ & $585.4 \mathrm{bc}$ & $61.8 \mathrm{~b}$ \\
\hline & NPKMgS1 & $311.0 \mathrm{bc}$ & $41.2 \mathrm{ab}$ & $361.1 b$ & $23.4 \mathrm{ab}$ & 132.3 & $556.8 \mathrm{~b}$ & $541.4 \mathrm{~b}$ & $49.1 \mathrm{ab}$ \\
\hline & NPKMgS2 & $284.2 \mathrm{bc}$ & $45.5 \mathrm{ab}$ & $326.8 b$ & 23.7ab & 148.3 & $476.0 \mathrm{ab}$ & 477.6ab & $49.6 \mathrm{ab}$ \\
\hline & NPKMgS3 & $326.6 \mathrm{bc}$ & $47.0 \mathrm{~b}$ & $406.9 \mathrm{~b}$ & $25.3 \mathrm{ab}$ & 167.6 & $568.2 \mathrm{~b}$ & $762.4^{c}$ & $59.5 \mathrm{ab}$ \\
\hline & $F$-value & $8.1^{* * *}$ & $3.7^{*}$ & $8.3^{* * *}$ & $4.7^{* *}$ & 2.0 & $4.3^{*}$ & $13.4^{* * *}$ & $8.3^{* * *}$ \\
\hline & SE & 24.4 & 3.63 & 30.2 & 1.80 & 11.6 & 37.9 & 41.2 & 3.32 \\
\hline \multirow[t]{9}{*}{2010} & $\mathrm{AC}$ & 136.0 & $39.4 a$ & 171.3 & $13.8 \mathrm{a}$ & $151.9 \mathrm{a}$ & $158.4 a$ & $237.9 a$ & 43.8 \\
\hline & NP. & 187.6 & $54.2 \mathrm{ab}$ & 250.9 & $20.4 \mathrm{abc}$ & $229.7 b c$ & 247.6ab & $535.8 \mathrm{~b}$ & 56.8 \\
\hline & NPK & 212.9 & $68.2 b$ & 247.1 & $22.8 \mathrm{bc}$ & $252.4 \mathrm{c}$ & $294.1 \mathrm{~b}$ & $623.6 \mathrm{~b}$ & 52.9 \\
\hline & NPKMgS1 & 187.4 & $60.3 \mathrm{ab}$ & 284.6 & $23.7 \mathrm{c}$ & $220.7 b c$ & $292.1 b$ & $469.6 \mathrm{~b}$ & 56.6 \\
\hline & NPKMgS2 & 195.5 & $61.8 \mathrm{~b}$ & 228.4 & $15.7 \mathrm{ab}$ & 172.6ab & 252.1ab & $494.6 \mathrm{~b}$ & 54.1 \\
\hline & NPKMgS3 & 200.6 & $61.7 \mathrm{~b}$ & 243.6 & $20.7 \mathrm{abc}$ & $215.9 b c$ & $282.7 \mathrm{~b}$ & $522.1 \mathrm{~b}$ & 48.5 \\
\hline & $F$-value & 1.8 & $4.5^{* *}$ & 2.2 & $5.7^{* *}$ & $7.5^{* * *}$ & $5.3^{* *}$ & $13.9^{* * *}$ & 1.5 \\
\hline & SE & 19.9 & 4.72 & 25.1 & 1.66 & 13.7 & 22.1 & 34.9 & 4.21 \\
\hline & $F$-value & $3.5^{* *}$ & $3.5^{* *}$ & $4.5^{* * *}$ & $2.7^{* *}$ & $6.0^{* * *}$ & 1.7 & $4.7^{* * *}$ & $3.2 * *$ \\
\hline
\end{tabular}

***,** ${ }^{*}$ significant at $p<0.001 ;<0.01 ;<0.05$, respectively; SE-Standard error; ${ }^{\text {a }}$ within a year, means within a column followed by the same letter indicates a lack of significant difference between the treatments.

The first three principal components (PCs) with an eigenvalue $\geq 1.0$ accounted for $95.39 \%$ of the total variance in the data. The contributions of the first two PCs were $51.93 \%$, and $26.06 \%$. Six variables with a score higher than 0.70 on PC1 were $\mathrm{K}, \mathrm{Mg}, \mathrm{N}, \mathrm{Cu}, \mathrm{SD}$, and $\mathrm{Y}$ (Table A3). The highest contribution to PC2 was positively exerted by $\mathrm{P}$ and $\mathrm{Ca}$, but negatively by $\mathrm{Zn}$ and $\mathrm{PD}$. The eigenvectors for the examined variables were scattered on the first two PCA axes (Figure 4). The closest to the absolute of 1 was $\mathrm{Y}$, and SD, followed by $\mathrm{K}, \mathrm{Mg}$, and $\mathrm{N}$, which were positively correlated with PC1. The significant impact of $\mathrm{K}$, concomitant with $\mathrm{N}$ on yield, was corroborated by the stepwise regression analysis (Table A4, Equation (A13)). The model obtained clearly indicates $\mathrm{N}$ and $\mathrm{K}$ as the two key nutrients responsible for WOSR yield. Pod and seed densities as the key yield component were driven by a broader set of variables (Table A4, Equations (A14) and (A15)). The dominant impact of K on SD was significantly corrected by the excessive amount of $\mathrm{Ca}$ and $\mathrm{Cu}$ in WOSR at physiological maturity. The main reason was their extreme accumulation in both seeds and post-harvest residues in 2010. TSW showed an opposite trend to SD location on the scatter plot, and was defined by $\mathrm{K}$ and $\mathrm{Cu}$ (Table A4, Equation (A16)). 


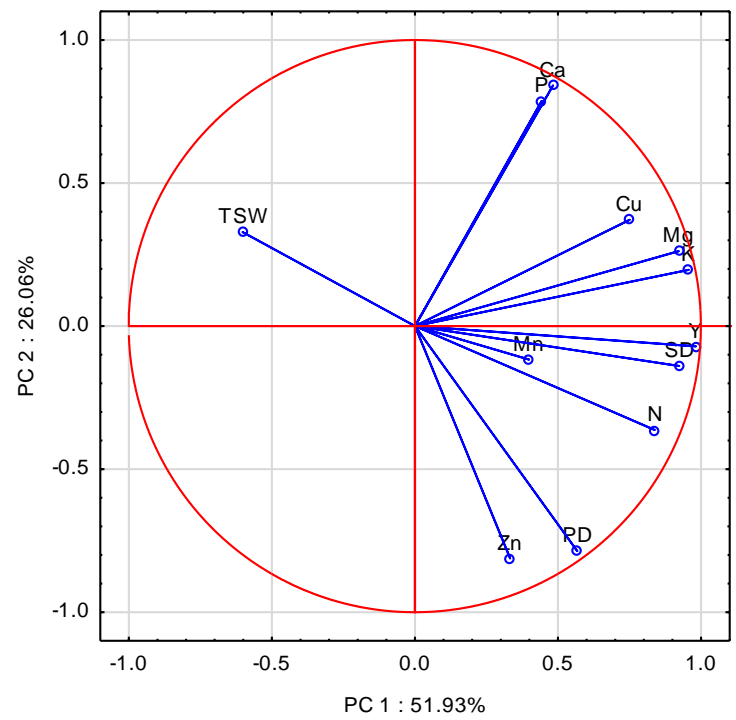

Figure 4. Score plot of WOSR components and nutrient accumulated in total WOSR biomass at harvest in PC1 and PC2 axes. Y-Yield, SD-Seed Density, PD—Pod Density, TSW-Thousand Seed Weight, $\mathrm{N}, \mathrm{P}, \mathrm{K}, \mathrm{Mg}, \mathrm{Ca}, \mathrm{Mn}, \mathrm{Zn}, \mathrm{Cu}-$ nutrients.

\subsection{Nutrient Remobilization Quota during the Seed Filling Period}

The primary sources of nutrients for growing seeds are their resources accumulated in the vegetative tissues of a seed crop before flowering. The size of these resources was evaluated by the index known as the nutrient remobilization quota (NRQ). The positive sign of this index for a given nutrient shows that its pre-flowering resources are sufficient to cover the requirements of the growing seeds. The negative sign indicates the net uptake a particular nutrient during the SFP from soil. The NRQ values for particular nutrients, averaged over years and fertilization treatments, were as follows:

$$
\begin{gathered}
\text { Macronutrients, } \mathrm{kg} \mathrm{ha}^{-1}: \mathrm{N}(+103.4>\mathrm{P}(+13.7)>\mathrm{Mg}(+4.5)>\mathrm{K}(-37.2)>\mathrm{Ca}(-95.7) . \\
\text { Micronutrients, } \mathrm{g} \mathrm{ha}^{-1}: \mathrm{Zn}(+67.4)>\mathrm{Cu}(-2.2)>\mathrm{Mn}(-48.7) .
\end{gathered}
$$

The orders obtained clearly show that the pre-flowering resources of $\mathrm{N}, \mathrm{P}, \mathrm{Mg}$, and $\mathrm{Zn}$ were sufficiently high to cover the requirements of the growing seeds. In the case of $\mathrm{K}$, and $\mathrm{Ca}$ for macronutrients, and for $\mathrm{Mn}$, and $\mathrm{Cu}$ for micronutrients, these resources were insufficient, forcing plants to uptake them from soil. The evaluation of NRQ with respect to a given nutrient contribution in seed requirements was shown by using an index, termed as nutrient reutilization coefficient (NRC). An index value below 100\% clearly indicates that the amount of the remobilized nutrient from its pre-flowering resources was too low to cover the requirements of the growing seeds. The values above $100 \%$ indicate a surplus of a remobilized nutrient, which was probably used for pod growth. The negative indices of NRC inform one that the seed requirements were covered by nutrients taken up by WOSR plants from soil during their post-flowering growth (Table A6).

The NRQ models of the studied nutrients are complicated, due to the dependence of the NRQ for the majority of nutrients on the interaction of weather and fertilization treatments (Table 7). The NRQ for N was the highest among the studied nutrients. In 2009, it was, on average, almost 4-fold higher than in 2008. Plants fertilized with MgS showed a significantly higher NRQ than those fertilized by NPK. This trend was the strongest in 2010. The NRQ for P was many-fold lower, but showed 7-fold variability from $4.3 \mathrm{~kg} \mathrm{ha}^{-1}$ in 2009 to $31.7 \mathrm{~kg} \mathrm{ha}^{-1}$ in 2010. A positive impact of MgS on P-NRQ was recorded in two contrastive years, i.e., 2008 and 2010. 
Table 7. Nutrient remobilization quota during the seed filling period.

\begin{tabular}{|c|c|c|c|c|c|c|c|c|c|}
\hline \multirow{2}{*}{$\begin{array}{c}\text { Year } \\
(\mathrm{Y})\end{array}$} & \multirow{2}{*}{$\begin{array}{c}\text { Factor } \\
\text { (F) }\end{array}$} & \multicolumn{5}{|c|}{ Macronutrients, $\mathrm{kg} \mathrm{ha}^{-1}$} & \multicolumn{3}{|c|}{ Micronutrients, $\mathrm{g} \mathrm{ha}^{-1}$} \\
\hline & & $\mathbf{N}$ & $\mathbf{P}$ & $\mathbf{K}$ & Mg & $\mathrm{Ca}$ & Zn & Mn & $\mathrm{Cu}$ \\
\hline \multirow[t]{8}{*}{2008} & $\mathrm{AC}$ & 16.2 & $2.7 \mathrm{a}$ & $-152.8 b$ & $-2.8 \mathrm{a}$ & $-155.6 b$ & $11.3 a$ & $-34.7 b c$ & $-14.4 \mathrm{ab}$ \\
\hline & $\mathrm{NP}$ & 43.1 & $22.2 b$ & $-120.0 b$ & $7.9 \mathrm{~b}$ & $-114.2 b$ & $116.8 \mathrm{~b}$ & $25.4 \mathrm{c}$ & $-4.4 b$ \\
\hline & NPK & 41.5 & $6.2 a$ & $-248.7 a b c$ & $0.4 \mathrm{ab}$ & $-186.2 \mathrm{ab}$ & $56.5 \mathrm{ab}$ & $-85.6 \mathrm{ab}$ & $-19.0 \mathrm{ab}$ \\
\hline & NPKMgS1 & 59.2 & $9.8 \mathrm{ab}$ & $-205.9 b c$ & $2.0 \mathrm{ab}$ & $-150.3 b$ & $101.6 \mathrm{~b}$ & $-75.9 b$ & $-14.0 \mathrm{ab}$ \\
\hline & NPKMgS2 & 55.1 & $9.5 \mathrm{a}$ & $-379.6 a$ & $1.6 \mathrm{ab}$ & $-250.4 a$ & $68.1 \mathrm{ab}$ & $-81.7 \mathrm{ab}$ & $-22.8 \mathrm{a}$ \\
\hline & NPKMgS3 & 51.4 & $9.4 \mathrm{a}$ & $-331.5 \mathrm{ab}$ & $-1.7 \mathrm{a}$ & $-194.8 \mathrm{ab}$ & $59.0 \mathrm{ab}$ & $-178.9 a$ & $-23.5 a$ \\
\hline & $F$-value & 0.9 & $5.6^{* *}$ & $7.0^{* * *}$ & $3.4^{*}$ & $6.5^{* *}$ & $6.9^{* * *}$ & $9.5^{* * *}$ & $4.2 *$ \\
\hline & SE & 16.7 & 2.80 & 38.3 & 2.04 & 18.3 & 14.2 & 21.8 & 3.46 \\
\hline \multirow[t]{8}{*}{2009} & AC & $61.3 a$ & $-0.9 a$ & 129.7ab & $4.1 \mathrm{a}$ & -47.5 & $-26.6 a$ & $-13.6 b$ & 3.8 \\
\hline & NP. & $147.6 \mathrm{~b}$ & $3.0 \mathrm{a}$ & $39.7 a$ & $9.8 \mathrm{ab}$ & -44.8 & $109.9 \mathrm{ab}$ & $117.3 \mathrm{~cd}$ & 17.7 \\
\hline & NPK & $145.9 \mathrm{~b}$ & $9.5 a$ & $91.1 \mathrm{a}$ & $12.5 \mathrm{~b}$ & -15.9 & $30.4 \mathrm{ab}$ & $-7.5 b$ & 17.8 \\
\hline & NPKMgS1 & $212.5 b$ & $8.8 \mathrm{a}$ & $232.5 b$ & $11.8 \mathrm{ab}$ & -6.1 & $164.9 \mathrm{~b}$ & $196.4 d$ & 32.5 \\
\hline & NPKMgS2 & $174.1 \mathrm{~b}$ & $4.6 a$ & $90.4 \mathrm{a}$ & $6.8 \mathrm{ab}$ & -39.3 & $70.0 \mathrm{ab}$ & $68.2 \mathrm{bc}$ & 15.3 \\
\hline & NPKMgS3 & $187.1 \mathrm{~b}$ & $0.7 \mathrm{a}$ & $109.7 \mathrm{ab}$ & $11.4 \mathrm{ab}$ & -37.2 & 71.4ab & $-151.1 \mathrm{a}$ & 18.3 \\
\hline & $F$-value & $8.8^{* * *}$ & 2.9 * & $4.8^{* *}$ & $3.2 *$ & 0.9 & $3.0 *$ & $20.0 * * *$ & 1.8 \\
\hline & SE & 17.5 & 2.46 & 29,5 & 1.85 & 17.6 & 37.9 & 27.0 & 6.94 \\
\hline \multirow[t]{9}{*}{2010} & $\mathrm{AC}$ & $78.8 \mathrm{ab}$ & $28.7 a$ & 10.3 & $5.2 \mathrm{ab}$ & -34.8 & 47.3 & $1.3 \mathrm{~d}$ & -13.2 \\
\hline & NP. & 77.0ab & $25.0 \mathrm{a}$ & 0.5 & $1.9 \mathrm{ab}$ & -112.0 & 105.2 & $-157.6 b$ & -15.4 \\
\hline & NPK & $55.8 \mathrm{a}$ & $24.2 \mathrm{a}$ & -16.0 & $0.9 \mathrm{ab}$ & -75.6 & 24.4 & $-304.6 a$ & -12.8 \\
\hline & NPKMgS1 & $177.6 \mathrm{~b}$ & $29.7 \mathrm{a}$ & -23.5 & $-1.6 a$ & -98.3 & 48.9 & $-15.3 c$ & -8.8 \\
\hline & NPKMgS2 & $167.2 b$ & $47.3 b$ & 50.2 & $6.6 b$ & -86.9 & 114.9 & $-29.7 b c$ & -2.5 \\
\hline & NPKMgS3 & $110.7 \mathrm{ab}$ & $35.4 \mathrm{ab}$ & 54.7 & $3.5 \mathrm{ab}$ & -72.0 & 38.3 & $-148.3 b$ & 6.2 \\
\hline & $F$-value & $4.3^{* *}$ & $5.1^{* *}$ & 2.0 & $3.6^{*}$ & 2.1 & 1.5 & $7.0^{* * *}$ & 1.9 \\
\hline & SE & 24.4 & 3.82 & 23.6 & 1.58 & 18.3 & 30.3 & 44.5 & 5.98 \\
\hline & $F$-value & 2.1 * & $5.2^{* * *}$ & $6.4^{* * *}$ & 1.8 & 2.5 * & $5.5^{* * *}$ & $17.3^{* * *}$ & 1.5 \\
\hline
\end{tabular}

***,**, significant at $p<0.001 ;<0.01 ;<0.05$, respectively; SE-Standard error; ${ }^{a}$ within a year, means within a column followed by the same letter indicates a lack of significant difference between the treatments.

The annual trend of NRQ for Mg was opposite to that recorded for P, but did not show a year-to-year variability. The NRQ for K showed extremely high variability, from highly negative values in 2008, to highly positive ones in 2009. The most marked variability, both positive and negative, was observed on plots fertilized with MgS. The NRQ for Zn was highly variable, reaching the highest value for different treatments, i.e., for the NP plot in 2008, NPKMgS1 in 2009, and NPKMgS2 in 2008. The NRQ indices for Mn were highly variable, reaching, averaged over fertilization treatments, negative values in 2008 and 2010, but positive in 2009. In all years, the negative values were the attribute of the NPK and NPKMgS3 treatments. A similar pattern was observed for $\mathrm{Cu}$, but in 2009, all indices were positive.

The first three principal components (PCs) with an eigenvalue $\geq 1.0$ accounted for $86.72 \%$ of the total variance in the data. The contributions of the first two PCs were $40.36 \%$, and $34.7 \%$. The set of variables with scores on PC1 higher than 0.70 comprised 5 of 12 analyzed characteristics. The highest, but at the same time negative loadings on $\mathrm{PC} 1$ were recorded for $\mathrm{Cu}, \mathrm{Mg}, \mathrm{Ca}, \mathrm{K}$, and $\mathrm{N}$ (Table A3). PC2 significantly and positively correlated with SD and PD, but negatively with P and TSW. The eigenvectors for the examined variables were scattered on the two first PCA axes (Figure 5). The closest to the absolute of 1 were $\mathrm{Cu}$ and $\mathrm{N}$, followed by $\mathrm{Mg}$. Seed yield and SD approached, however, the absolute of 0 . A significant, but negative impact of $\mathrm{K}$, concomitant with $\mathrm{Cu}$ on $\mathrm{Y}$ and $\mathrm{SD}$, was corroborated by the stepwise regression analysis (Table A4, Equations (A17) and (A18)). The model obtained clearly indicates that high and positive K-NRQ values negatively affected yield. The positive impact of $\mathrm{Cu}$ was due to its high net values in 2010, but were concomitant with low yield. Pod density was positively driven by N-NRQ, and negatively by the P-NRQ. Low $\mathrm{N}$ remobilization was observed in 2008. The negative sign for $P$ is misleading, because its high remobilization in 2010 did not result in a high yield (Table A4, Equation (A19)). TSW showed an opposite trend to SD, but positive to P location on the scatter plot (Table A4, Equation (A20)). The positive impact of P on TSW is due to its 
low remobilization in 2009. An opposite trend was recorded for $\mathrm{K}$ and $\mathrm{Mn}$, which showed the highest NRQ values in 2009, but with no positive impact on seed yield (Table A1).

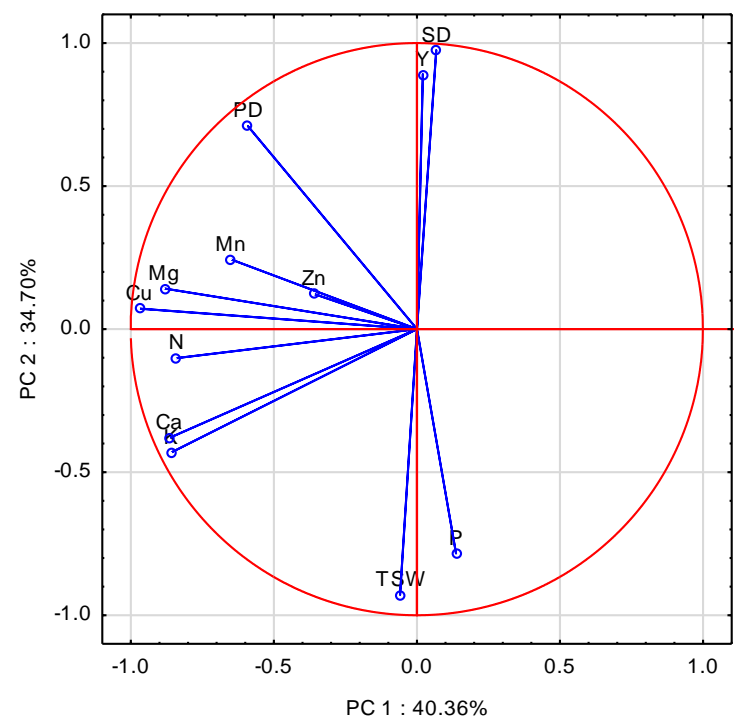

Figure 5. Score plot of WOSR components and a particular Nutrient Remobilization Quota in PC1 and PC2 axes. Y-Yield, SD—Seed Density, PD—Pod Density, TSW—Thousand Seed Weight, N, P, K, $\mathrm{Mg}, \mathrm{Ca}, \mathrm{Mn}, \mathrm{Zn}, \mathrm{Cu}-$ nutrients.

\subsection{Post-Flowering Nutrient Uptake}

The net balance for post-flowering uptake of a particular nutrient, averaged over years and fertilization treatments, was as follows:

$$
\begin{gathered}
\text { macronutrients, } \mathrm{kg} \mathrm{ha}^{-1}: \mathrm{Ca}(110.8)>\mathrm{K}(72.6)>\mathrm{N}(34.1)>\mathrm{P}(18.7)>\mathrm{Mg}(6.9) ; \\
\text { micronutrients, } \mathrm{g} \mathrm{ha}^{-1}: \mathrm{Mn}(204.7)>\mathrm{Zn}(117.9)>\mathrm{Cu}(18.7) .
\end{gathered}
$$

The amount of a particular nutrient taken up by plants from soil during the SFP, with the exception of $\mathrm{N}$ and $\mathrm{Zn}$, was governed by the interaction of weather and fertilization treatments (Table 8). The highest uptake of $\mathrm{N}$ was recorded in 2008. In other years, in spite of a high variability between treatments, the average $\mathrm{N}$ uptake was near zero. P uptake followed the pattern recorded for seed yield (Table A1). Net P uptake during SFP in 2008, the year with the highest yield, was 4-fold higher than 2010, the year with the lowest yield. The impact of fertilization treatments on P uptake was variable year-to-year, being, on average, the highest for plants fertilized with NPK. The highest post-flowering K uptake was recorded in 2008, being the highest on the NPKMgS2 plot, which had the highest yield during the entire study. In 2009, no extra K was taken by plants during the SFP. In 2010, a net K uptake was recorded for the first four treatments, but the highest was recorded on the NPKMgS2 plot, which also had the highest yield. The net uptake of Mg and Ca during SFP followed the same annual pattern, reaching the highest values in 2008. In all years, but especially in 2008, plants fertilized with NPKMgS2 showed the highest Ca uptake. The post-flowering uptake of $\mathrm{Zn}$ was more than 3-fold higher in 2009 than in other years. The impact of fertilization treatments was apparent only in 2008, when the highest net $\mathrm{Zn}$ uptake was recorded on the NPKMgS2 plot. A reverse pattern was recorded for Mn. In 2008 and 2009, the highest net Mn uptake was found on the NPKMgS3 plot, but in 2010, on the NPK plot. Post-flowering Cu uptake was recorded in 2008 and 2010. In 2009, net Cu uptake was recorded for four of the six treatments. It was highest on the AC plot. 
Table 8. Post-flowering nutrient uptake by WOSR plants.

\begin{tabular}{|c|c|c|c|c|c|c|c|c|c|}
\hline \multirow{2}{*}{$\begin{array}{l}\text { Year } \\
(Y)\end{array}$} & \multirow{2}{*}{$\begin{array}{c}\text { Factor } \\
\text { (F) }\end{array}$} & \multicolumn{5}{|c|}{ Macronutrients, $\mathrm{kg} \mathrm{ha}^{-1}$} & \multicolumn{3}{|c|}{ Micronutrients, $\mathrm{g} \mathrm{ha}^{-1}$} \\
\hline & & $\mathbf{N}$ & $\mathbf{P}$ & $\mathbf{K}$ & $\mathrm{Mg}$ & $\mathrm{Ca}$ & $\mathrm{Zn}$ & Mn & $\mathrm{Cu}$ \\
\hline \multirow[t]{8}{*}{2008} & $\mathrm{AC}$ & 67.0 & $24.7 \mathrm{ab}$ & $181.3 a$ & $12.4 \mathrm{ab}$ & 166.1a & 83.0ab & $127.4 \mathrm{ab}$ & $25.8 \mathrm{ab}$ \\
\hline & NP. & 93.7 & $13.4 \mathrm{a}$ & $159.7 \mathrm{a}$ & $4.8 \mathrm{a}$ & $127.6 a$ & $12.3 \mathrm{a}$ & $104.8 \mathrm{a}$ & $19.0 \mathrm{a}$ \\
\hline & NPK & 115.2 & $34.1 \mathrm{~b}$ & 293.0abc & $13.8 \mathrm{ab}$ & $201.7 \mathrm{ab}$ & $101.0 \mathrm{~b}$ & $235.1 \mathrm{c}$ & $35.3 b$ \\
\hline & NPKMgS1 & 85.7 & $26.6 \mathrm{ab}$ & $248.0 \mathrm{ab}$ & $11.1 \mathrm{ab}$ & $164.7 \mathrm{a}$ & $48.0 \mathrm{ab}$ & $226.4 \mathrm{bc}$ & $29.0 \mathrm{ab}$ \\
\hline & NPKMgS2 & 135.4 & $37.4 \mathrm{~b}$ & $434.1 \mathrm{c}$ & $14.6 \mathrm{ab}$ & $268.3 b$ & $108.7 \mathrm{~b}$ & $259.8 \mathrm{~cd}$ & $41.6 \mathrm{c}$ \\
\hline & NPKMgS3 & 102.9 & $32.4 \mathrm{~b}$ & $379.3 \mathrm{bc}$ & $16.5 b$ & $210.2 \mathrm{ab}$ & $102.9 \mathrm{~b}$ & $346.8 \mathrm{~d}$ & $40.2 \mathrm{bc}$ \\
\hline & $F$-value & 1.58 & $5.1^{* *}$ & $3.1 *$ & $6.7^{* *}$ & $4.0 *$ & $5.4^{* *}$ & $14.2^{* * *}$ & $5.4^{* *}$ \\
\hline & SE & 18.9 & 3.80 & 39.6 & 2.32 & 18.7 & 19.2 & 23.6 & 26.9 \\
\hline \multirow[t]{8}{*}{2009} & $\mathrm{AC}$ & 31.6 & 17.7 & $-106.7 \mathrm{ab}$ & 4.6 & 58.7 & 238.0 & $151.4 \mathrm{ab}$ & 8.2 \\
\hline & NP. & -4.6 & 20.4 & $-8.3 b$ & 2.1 & 59.0 & 159.9 & $77.1 \mathrm{a}$ & -1.4 \\
\hline & NPK & 40.5 & 19.2 & $-51.6 b$ & 1.9 & 33.5 & 296.0 & $260.3 b c$ & 1.9 \\
\hline & NPKMgS1 & -48.7 & 17.7 & $-195.8 \mathrm{a}$ & 2.1 & 22.1 & 160.9 & $37.7 \mathrm{a}$ & -13.7 \\
\hline & NPKMgS2 & -15.8 & 21.9 & $-54.9 b$ & 6.5 & 55.9 & 182.0 & $146.4 \mathrm{ab}$ & 2.5 \\
\hline & NPKMgS3 & -6.0 & 27.3 & $-69.6 a b$ & 3.2 & 54.2 & 242.5 & $418.9 \mathrm{c}$ & 1.4 \\
\hline & $F$-value & 2.5 & 1.3 & $4.5^{* *}$ & 1.0 & 0.8 & 1.2 & $14.2^{* * *}$ & 1.1 \\
\hline & SE & 20.5 & 3.16 & 30.4 & 1.81 & 18.0 & 50.6 & 36.9 & 6.93 \\
\hline \multirow[t]{8}{*}{2010} & $\mathrm{AC}$ & -2.0 & -2.7 & 8.8 & $0.1 \mathrm{a}$ & 45.0 & 25.6 & $61.6 a$ & 23.2 \\
\hline & NP. & 37.9 & 12.0 & 26.0 & $6.4 \mathrm{ab}$ & 128.8 & 30.8 & $278.2 \mathrm{bc}$ & 33.8 \\
\hline & NPK & 64.3 & 18.9 & 50.3 & 7.1ab & 91.0 & 111.2 & $416.7 \mathrm{c}$ & 28.7 \\
\hline & NPKMgS1 & -52.8 & 9.6 & 53.1 & $10.5 b$ & 115.9 & 101.8 & $134.6 \mathrm{ab}$ & 28.4 \\
\hline & NPKMgS2 & -39.9 & -1.2 & -16.7 & $1.8 \mathrm{ab}$ & 103.3 & 37.4 & $152.8 \mathrm{ab}$ & 22.4 \\
\hline & NPKMgS3 & 9.0 & 6.9 & -23.2 & $4.2 \mathrm{ab}$ & 88.7 & 80.9 & 248.9abc & 10.9 \\
\hline & $F$-value & 2.7 & 2.3 & 1.8 & $3.7 *$ & 2.3 & 1.6 & $7.1^{* * *}$ & 1.3 \\
\hline & SE & 27.0 & 5.44 & 24.5 & 1.97 & 19.2 & 29.8 & 47.2 & 7.04 \\
\hline $\mathrm{Y} \times \mathrm{F}$ & $F$-value & 1.7 & $2.9^{* *}$ & $6.2^{* * *}$ & $3.3^{* *}$ & $3.6^{* *}$ & 0.9 & $6.0^{* * *}$ & $2.2^{*}$ \\
\hline
\end{tabular}

***,*** significant at $p<0.001 ;<0.01 ;<0.05$, respectively; SE-Standard error; ${ }^{\text {a }}$ within a year, means within a column followed by the same letter indicate a lack of significant difference between the treatments.

The first three principal components (PCs) with an eigenvalue $\geq 1.0$ accounted for $90.46 \%$ of the total variance in the data. The contributions of the first two PCs were $49.8 \%$ and $30.95 \%$. The PC1 was significantly correlated with 7 of 12 analyzed characteristics. The highest, and at the same time positive coefficients of correlation (eigenvalue $\geq 1.0$ ) were recorded for $\mathrm{K}, \mathrm{Mg}, \mathrm{Ca}, \mathrm{P}, \mathrm{N}, \mathrm{SD}$, and Y (Table A3). PC2 significantly, and positively, correlated with $\mathrm{Cu}$, but negatively with $\mathrm{Zn}$, and PD. The eigenvectors for the examined variables were broadly scattered on the two first PCA axes (Figure 6a). The closest to the absolute of 1 of the PC1 axe was P, followed by $\mathrm{Y}$, and SD, which were positively correlated with PC1 (Table A3). A deeper explanation of the observed relationships can be seen on the PC1 and PC3 scatter plot (Figure $6 \mathrm{~b}$ ). The closest to the absolute of 1 on the PC1 axe were $\mathrm{Mg}, \mathrm{P}, \mathrm{K}, \mathrm{Cu}, \mathrm{Y}$ and SD. Stepwise analysis clearly showed that yield was determined by $\mathrm{K}$ and $\mathrm{Cu}$ (Table A4, Equation (A21)). The negative impact of $\mathrm{Cu}$ was due to its high uptake during the post-flowering period in 2010. $\mathrm{K}$ shortage resulted in a significantly lower $\mathrm{PD}$ and $\mathrm{SD}$ in this particular year, as corroborated by the regression models developed (Table A4, Equations (A22) and (A23)). TSW showed a completely opposite location on the scatter plot with respect to $\mathrm{Y}, \mathrm{SD}$, and $\mathrm{P}$. The highest post-flowering $\mathrm{P}$ uptake was in 2008, the year with the highest yield, but the lowest TSW (Table A4, Equation (A24)). 


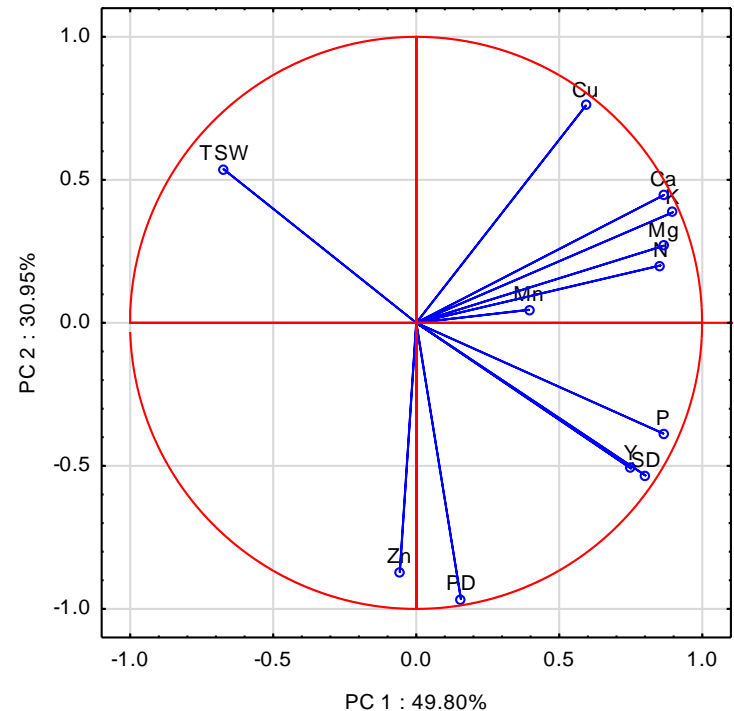

(a)

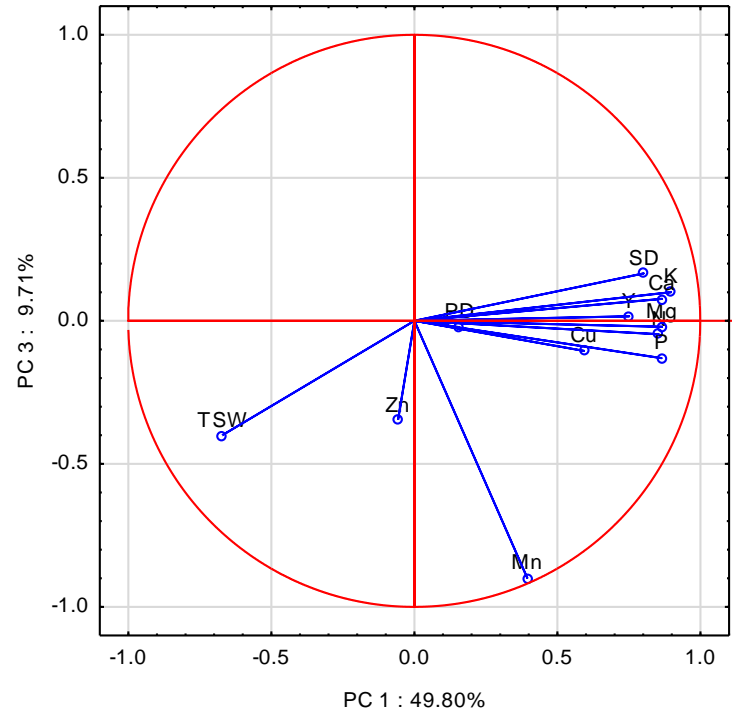

(b)

Figure 6. (a) Score plot of WOSR components and a particular Post-flowering Nutrient Uptake in PC1 and. PC2 axes. (b) Score plot of WOSR components and a particular Nutrient Post-flowering Uptake in PC1 and PC3 axes. Y-Yield, SD—Seed Density, PD—Pod Density, TSW—Thousand Seed Weight, $\mathrm{N}, \mathrm{P}, \mathrm{K}, \mathrm{Mg}, \mathrm{Ca}, \mathrm{Mn}, \mathrm{Zn}, \mathrm{Cu}-$ nutrients.

\section{Discussion}

Yield of the seed crop is a function of two basic yield components, i.e., seed number per unit area, expressed as seed density (SD) and an individual seed weight, presented as thousand seed weight, TSW [18]. High yields of this crop are much more dependent on SD than on TSW [23]. In our study, both yield components exerted an opposite impact on WOSR yield:

$$
\begin{gathered}
\text { SD: } \mathrm{Y}=34.9 \mathrm{SD}+1422 \text { for } n=18 . R^{2}=0.92, \text { and } p<0.001 \\
\text { TSW: } \mathrm{Y}=-954.7 \mathrm{TSW}+9297 \text { for } n=18 . R^{2}=0.48 \text {, and } p<0.001
\end{gathered}
$$

The recorded trends clearly indicate the occurrence of a phenomenon known as yield components compensation [18]. In our case, the increase in SD resulted in a decrease of TSW and vice versa. The above presented relationships clearly show that SD was the dominant yield forming factor. A TSW increase of $1 \mathrm{~g}$ resulted in a yield decrease of $0.95 \mathrm{t} \mathrm{ha}^{-1}$.

The degree of SD expression depends on numerous processes that affect WOSR growth from the rosette stage up to the end of the pod growth phase. The key period for seed set extends from the beginning of flowering to the full stage of pod development [2]. The survival of a young pod is a result of its competition for assimilates and nutrients, with the simultaneously occurring growth of secondary branches $[20,21]$. It can therefore be assumed that the nutritional status of WOSR at the onset of flowering can be treated as the basis for assimilate production and a source of nutrients both for the growing pods and seeds, and secondary inflorescences. It can also be assumed that SD expresses the sink capacity for both assimilates and nutrients. Hence, TSW, in accordance with the YCC theory, is a measure of sink capacity realization for an individual seed.

The objective of this study was to determine the most reliable plant trait (individual plant organ, whole plant, or artificially developed traits), which would allow the best set of nutrients, responsible for SD, TSW to be defined, as well as the final seed yield formation during the SFP. The primary question concerns the potential of winter oilseed rape, expressed by the amount of nutrients accumulated in vegetative tissues at the onset of flowering, to fix a respective number of pods and seeds, next to fill them, and ultimately, to define final seed yield. The key nutrients fulfilling these 
assumptions were $\mathrm{Mg}, \mathrm{K}, \mathrm{Ca}$ and to a lesser extent $\mathrm{N}, \mathrm{Cu}, \mathrm{Zn}$, and $\mathrm{Mn}$. Magnesium was found to be the key nutrient, responsible for yield, SD and TSW. The positive impact of Mg accumulated in WOSR at the onset of flowering on Y, SD, but negatively on TSW, which indicates that SD is the yield driver (Figure 1a,b). The number of seeds was limited by a shortage of Mg in WOSR at the onset of flowering; in contrast, TSW was reduced by it excess. This phenomenon is in accordance with the YCC theory, which states that the lower the SD, the higher the TSW, and vice versa. The yield prognosis based on the amount of $\mathrm{Mg}$ in WOSR plants at the onset of flowering fully corroborates the importance of WOSR leaves as a diagnostic organ for this crop [24].

The contribution of PC1 to the total variation in the studied data was used as the criterion to select WOSR traits to define the basic set of nutrients for determining SD, TSW, and final seed yield during the SFP. The order obtained was as follows:

Seeds $(60.27 \%)>$ total uptake $(51.93 \%)>$ PNU $(49.8 \%)>$ post-harvest residues $(46.87 \%)>$ NRQ $(40.36 \%)$.

The amount of nutrients accumulated in WOSR seeds was revealed as the as the key diagnostic trait for SD, TSW, and final seed yield prognosis. For seeds, 8 of 12 studied variables, with scores on PC1 higher than 0.7 , were significantly correlated with each other. Two variables, i.e., $\mathrm{K}$ and $\mathrm{Mg}$ explain $98 \%$ of SD and Y variability (Figure 2a,b; Table A4, Equations (A3) and (A4)). A shortage of both nutrients in mature seeds, leading to a decreased SD, consequently resulted in a yield drop. The first signal of Mg deficiency in WOSR leaves in this study was recorded at the onset of flowering, as reported by [24]. An insufficient Mg supply to WOSR plants during SFP can result in (i) decreased assimilate production by leaves and pods, (ii) reduction in the length of photosynthetic activity of leaves and pods, (iii) disturbance in assimilate loading to the phloem [25].

The shortage of Mg during SFP probably created a gap for a compensatory uptake of other cations, which was observed in the first line for $\mathrm{Ca}$, and to a lesser extent for $\mathrm{Cu}$ and $\mathrm{Mn}$, as recorded in 2010. However, in accordance with the YCC theory (Equations (5a) and (5b)), any TSW increase led to a decline in both SD, and seed yield. This specific relationship between Ca and Mg in WOSR seeds was explained by the Ca: $\mathrm{Mg}$ ratio. In 2008, the year with the highest seed yield, this ratio was as 3.65:1. In 2009, it increased up to 4.76:1, whereas in 2010 it reached 7.61:1. The quadrate regression model, describing the relationship between $\mathrm{Ca}$ : $\mathrm{Mg}$ and $\mathrm{SD}$ was more reliable $\left(R^{2} ; p\right)$ than that of $\mathrm{Y}$ :

$$
\begin{aligned}
\mathrm{SD} & =1.78(\mathrm{Ca}: \mathrm{Mg})^{2}-36.5(\mathrm{Ca}: \mathrm{Mg})+195.7 \text { for } n=18, R^{2}=0.70 \text { and } p \leq 0.001 \\
\mathrm{Y} & =60.9(\mathrm{Ca}: \mathrm{Mg})^{2}-1112(\mathrm{Ca}: \mathrm{Mg})+7995 \text { for } n=18, R^{2}=0.53 \text { and } p \leq 0.01
\end{aligned}
$$

As results from Equation (5c), a Ca: Mg ratio of 9.4 resulted in the lowest SD of $38.46 \times 103$. Any narrowing of the Ca: Mg ratio led, however, to an exponential SD increase, consequently resulting in a higher seed yield. The observed $\mathrm{Ca}$ and $\mathrm{Mg}$ antagonism during the SFP of WOSR has recently been discovered for spelt wheat, also during the grain filling period [26].

The obtained results fully corroborate the hypothesis that sink capacity, rather than source capacity, is the key yield driver [27]. As suggested by Körner [28], sink strength through an exerted requirement for assimilates determines source activity (production of assimilates). The analysis of nutrient management during the SFP clearly indicates $\mathrm{K}$ as the key nutrient responsible for the sink capacity of WOSR, expressed by SD. Potassium accumulated in seeds was the key variable, affecting PD and Y, but not SD and TSW (Table A4, Equations (A5)-(A8)).

The analysis of other WOSR traits during the SFP showed that $\mathrm{K}$ accumulated in post-harvest residues also affected PD, SD, TSW, and finally, Y. The regression models for PD, SD and Y indicate a K shortage. The exception was TSW, which, as a rule, showed a negative response to the increasing amount of $\mathrm{K}$. These patterns have been corroborated by an evaluation of the total $\mathrm{K}$ uptake on the development of WOSR yield components. The opposite effect of K on PD, SD on one site and on TSW on the other one, corroborates the key importance of K for SD expression. The dominant impact 
of K management during the SFP on the development of yield components, and finally on seed yield, was supported by its net post-flowering uptake from soil. The net $\mathrm{K}$ uptake during this period affected both PD, SD, and finally seed yield. WOSR plants continue K net uptake up to the end of pod growth. After this phase, it stops or even declines, mostly due to fall of leaves and pods [29,30]. Potassium is the nutrient responsible for the transportation of assimilates from a plant's physiological source to its sink [31]. In the case of WOSR, this is a two-step process. The first stage refers to transportation of assimilates from leaves to the growing pod, which behaves as a temporary sink for both assimilates and nutrients. The adult pod is the key source of assimilates to the growing seeds [32,33].

The analysis of K management during SFP clearly showed a shortage of this nutrient in seeds. The main reason was a low amount of $\mathrm{K}$ in the post-harvest residues, and an insufficient uptake from soil during SFP. This eventually resulted in a decreased PD, subsequently leading to an SD decrease. The highest seed yield was recorded in 2008, during which the net $\mathrm{K}$ uptake from soil resources during SFP took place. The yield decreased in 2009, in spite of a high accumulation of $\mathrm{K}$ in vegetative WOSR tissues before flowering, and indicated low $\mathrm{K}$ re-translocation potential to the growing pods, and subsequently seeds. The data obtained fully corroborate and explain the study by Pan et al. [34], who stated that under low sink demand for assimilates induced by a shortage of $K$, photosynthetic activity of WOSR leaves also decreases.

Special attention should be devoted to the relationship between $\mathrm{K}$ management during the SFP, and $\mathrm{Ca}$; but together with $\mathrm{Mg}$, the amount of these three nutrients in seeds, averaged over years and fertilization treatments, was $11 \%, 8 \%$, and $46 \%$ of their total accumulation at harvest. For $\mathrm{K}$ and $\mathrm{Ca}$, the respective NRQ values were negative, indicating, in fact, a net of their post-flowering uptake. This was fully corroborated by PNU indices, which for both of these nutrients, were higher than their amount in seeds. The analysis of the impact of K-PNU on the post-flowering uptake of the other two nutrients was positive, showing, however, a much stronger relationship with Ca than $\mathrm{Mg}$ (Figure 7). The key reason of these synergic relationships was both a PD and SD increase in 2008, and 2010 in response to the net uptake of K. The higher sink capacity, as expressed by both yield components, resulted in a higher requirement for $\mathrm{Ca}$ and $\mathrm{Mg}$. As results from the developed regression models show, the net amount of $\mathrm{Ca}$ was a much stronger dependent on $\mathrm{K}-\mathrm{PN}_{\mathrm{a}} \mathrm{U}$. The strength of this dependency results from its dominant accumulation in pods [30]. The conducted study clearly showed that the requirement for $\mathrm{Ca}$ was determined by WOSR sink capacity. The much weaker relationship of $\mathrm{K}-\mathrm{PNU}$ with $\mathrm{Mg}$ can be explained by its high accumulation in seeds.

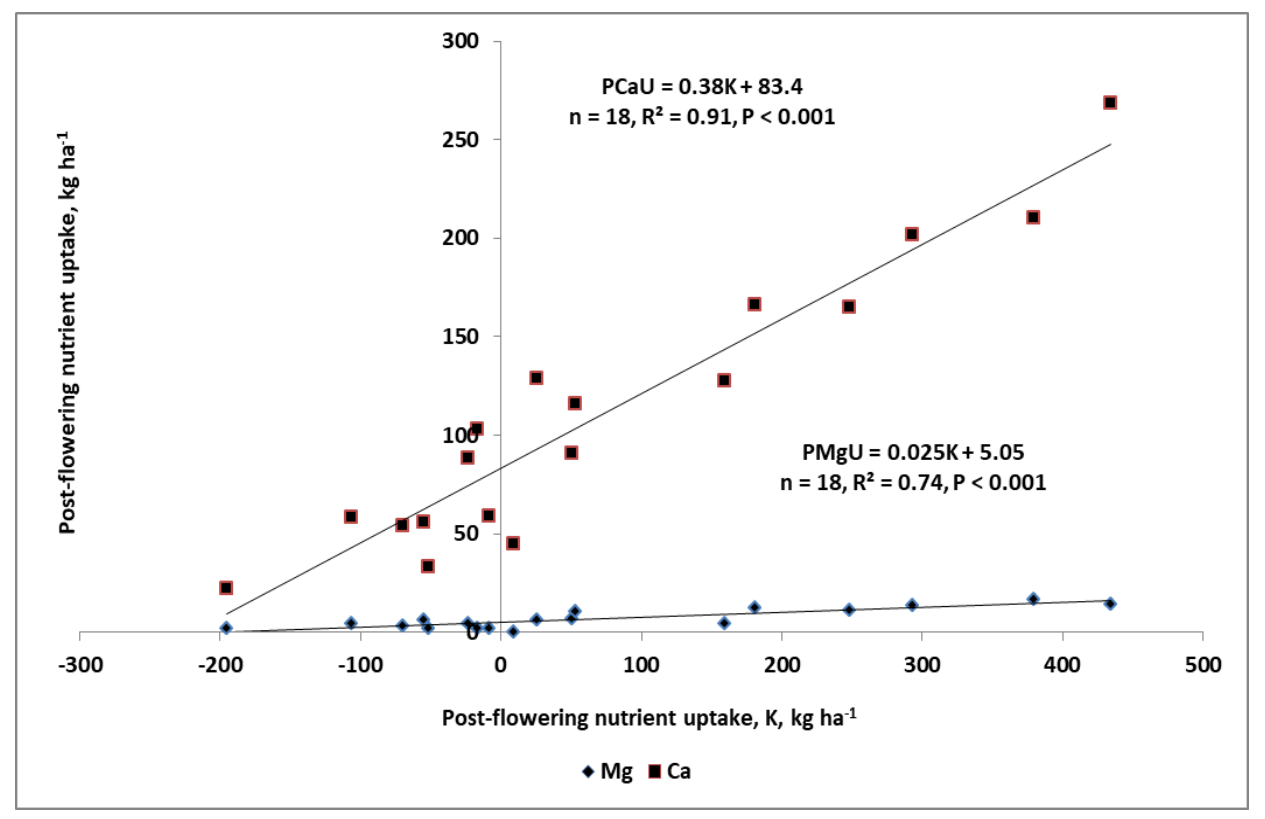

Figure 7. The impact of post-flowering $\mathrm{K}$ uptake on post-flowering uptake of calcium and magnesium. 


\section{Conclusions}

Seed yield of WOSR was determined by the supply of $\mathrm{K}$ and Mg. The action of both nutrients was to develop the sink capacity of the crop. The conducted study clearly showed that the sink capacity of WOSR, expressed by pod density, but especially by seed density, is a crucial factor for achieving high yields of this crop. The key nutritional factor responsible for sink capacity development was $\mathrm{K}$. Its impact on both yield components was positively supported by $\mathrm{N}$, and $\mathrm{Zn}$, but negatively by $\mathrm{Cu}$ and $\mathrm{Mn}$. The pre-flowering resources of $\mathrm{N}, \mathrm{P}, \mathrm{Mg}$, and $\mathrm{Zn}$, in spite of their high remobilization potential, were insufficient to cover the requirements of high-yielding WOSR. A net post-flowering uptake was recorded for all nutrients, but it was crucial for covering the WOSR requirement for $\mathrm{Ca}, \mathrm{K}$, $\mathrm{Mn}$, and $\mathrm{Cu}$. The net $\mathrm{K}$ uptake during the post-flowering period of WOSR development was crucial for both PD and SD. A greater SD resulted in a concomitant higher net uptake of $\mathrm{Ca}$ and $\mathrm{Mg}$. A shortage of $\mathrm{Mg}$ led to an excessive uptake of $\mathrm{Ca}$, subsequently resulting in both an $\mathrm{SD}$ and seed yield decrease. Seeds, as results from the PC1 contribution in the total variance of data show, were revealed as the best WOSR diagnostic trait, with respect to being able to evaluate the impact of nutrients on both the degree of yield component expression and seed yield.

Author Contributions: Conceptualization, W.G.; methodology, W.G. and W.S.; software, S.G.; validation, W.S. and S.G.; formal analysis, S.G.; data curation, W.S. and S.G.; writing-original draft preparation, W.S. and S.G.; writing-review and editing, W.G.; visualization, W.S.; supervision, W.G.; W.S. All authors have read and agreed to the published version of the manuscript.

Funding: This publication is being co-financed by the framework of Ministry of Science and Higher Education program as "Regional Initiative Excellence" in years 2019-2022, project no. 005/RID/2018/19.

Conflicts of Interest: The authors declare no conflict of interest.

\section{Appendix A}

Table A1. Yield components and seed yield of winter oilseed rape response to fertilization treatments.

\begin{tabular}{|c|c|c|c|c|c|}
\hline \multirow{3}{*}{$\begin{array}{l}\text { Year } \\
\text { (Y) }\end{array}$} & \multirow{3}{*}{$\begin{array}{l}\text { Factor } \\
\text { (F) }\end{array}$} & \multicolumn{3}{|c|}{ Yield Components $^{1}$} & \multirow{2}{*}{$\begin{array}{c}\text { Yield } \\
\mathrm{Y}\end{array}$} \\
\hline & & PD & $\mathrm{SD} \times 1000$ & TSW & \\
\hline & & \multicolumn{2}{|c|}{ No. $m^{-2}$} & $\mathrm{~g}$ & $\mathrm{~kg} \mathrm{ha}^{-1}$ \\
\hline \multirow[t]{8}{*}{2008} & $\mathrm{AC}$ & $5579 \mathrm{ab}$ & $71.2 \mathrm{a}$ & 4.98 & $3522 a$ \\
\hline & NP. & $5377 a$ & 89.3ab & 5.11 & $4547 \mathrm{ab}$ \\
\hline & NPK & 6450abc & $103.5 \mathrm{bc}$ & 4.75 & $4880 \mathrm{bc}$ \\
\hline & NPKMgS1 & 6914abc & $96.3 \mathrm{abc}$ & 4.88 & $4628 b$ \\
\hline & NPKMgS2 & $8605 \mathrm{bc}$ & $121.3 \mathrm{c}$ & 4.88 & $5807 \mathrm{c}$ \\
\hline & NPKMgS3 & $8935 c$ & $106.9 \mathrm{bc}$ & 4.81 & $5117 \mathrm{bc}$ \\
\hline & $F$-value & $4.7^{* *}$ & $5.7^{* *}$ & 1.0 & $9.4^{* * *}$ \\
\hline & SE & 695.9 & 7.11 & 0.13 & 245.1 \\
\hline \multirow[t]{8}{*}{2009} & $\mathrm{AC}$ & 9507 & $59.5 a$ & 4.93 & 2898a \\
\hline & NP. & 11525 & 77.5ab & 5.27 & $3907 a b$ \\
\hline & NPK & 13444 & $96.1 \mathrm{~b}$ & 5.34 & $5085 c$ \\
\hline & NPKMgS1 & 10743 & 83.1ab & 5.34 & $4388 \mathrm{bc}$ \\
\hline & NPKMgS2 & 12972 & $86.1 \mathrm{~b}$ & 5.15 & $4371 b c$ \\
\hline & NPKMgS3 & 11502 & $90.4 \mathrm{~b}$ & 5.38 & $4862 b c$ \\
\hline & $F$-value & 2.0 & $5.3^{* *}$ & 1.0 & $10.7^{* * *}$ \\
\hline & SE & 1010.9 & 5.91 & 0.17 & 245.7 \\
\hline \multirow[t]{8}{*}{2010} & $\mathrm{AC}$ & 3120 & $32.0 \mathrm{a}$ & 6.21 & $2223 a$ \\
\hline & NP. & 3078 & $40.5 \mathrm{ab}$ & 6.56 & $2989 \mathrm{ab}$ \\
\hline & NPK & 4489 & $41.6 \mathrm{ab}$ & 6.64 & 3112ab \\
\hline & NPKMgS1 & 5002 & $50.3 \mathrm{~b}$ & 6.39 & $3276 a b$ \\
\hline & NPKMgS2 & 3891 & $48.7 \mathrm{ab}$ & 6.35 & $3474 a b$ \\
\hline & NPKMgS3 & 4213 & $43.4 \mathrm{ab}$ & 6.62 & 3193ab \\
\hline & $F$-value & 2.3 & $4.0 *$ & 1.9 & $3.4^{*}$ \\
\hline & SE & 504.2 & 3.30 & 0.13 & 234.2 \\
\hline$Y \times F$ & $F$-value & 1.8 & 1.9 & 1.1 & $2.1^{*}$ \\
\hline
\end{tabular}

1 PD—numer of pod, pods $\mathrm{m}^{-2}$; SD—number of seeds, seeds $\mathrm{m}^{-2}$; TSW-Thousand Seed Weight, $\mathrm{g}$. SE-Standard error; ${ }^{* * *},{ }^{* *},{ }^{*}$ significant at $p<0.001 ;<0.01 ;<0.05$, respectively; SE-Standard error; ${ }^{\text {a }}$ within a year, means within a column followed by the same letter indicates a lack of significant difference between the treatments. 
Table A2. Spearman correlation matrix between nutrient accumulation, yield components and PCA factors.

\begin{tabular}{|c|c|c|c|c|c|c|c|c|c|}
\hline \multirow{2}{*}{ Variable } & \multicolumn{3}{|c|}{ WOSR Flowering } & \multicolumn{3}{|c|}{ Seeds } & \multicolumn{3}{|c|}{ Post-Harvest Residues } \\
\hline & PC1 & PC2 & PC3 & PC1 & PC2 & PC3 & PC1 & PC2 & PC3 \\
\hline $\mathrm{N}$ & 0.91 & 0.34 & -0.04 & 0.96 & -0.21 & 0.08 & 0.61 & -0.58 & -0.34 \\
\hline $\mathrm{P}$ & -0.36 & 0.68 & 0.54 & 0.06 & -0.91 & -0.39 & 0.59 & 0.41 & -0.55 \\
\hline $\mathrm{K}$ & 0.92 & 0.28 & -0.18 & 0.83 & -0.30 & -0.45 & 0.98 & 0.06 & 0.08 \\
\hline $\mathrm{Mg}$ & 0.76 & -0.22 & 0.53 & 0.96 & 0.09 & -0.22 & 0.81 & 0.48 & 0.13 \\
\hline $\mathrm{Ca}$ & 0.24 & 0.74 & 0.34 & 0.60 & -0.70 & 0.34 & 0.59 & 0.78 & 0.08 \\
\hline $\mathrm{Zn}$ & 0.89 & 0.39 & -0.11 & 0.73 & 0.29 & 0.60 & 0.01 & -0.73 & -0.66 \\
\hline Mn & 0.74 & 0.57 & -0.09 & 0.89 & 0.19 & 0.40 & 0.06 & 0.23 & -0.92 \\
\hline $\mathrm{Cu}$ & 0.94 & 0.28 & -0.12 & 0.61 & -0.62 & 0.45 & 0.77 & 0.41 & -0.30 \\
\hline $\mathrm{PD}^{1}$ & 0.84 & -0.35 & -0.27 & 0.78 & 0.48 & 0.33 & 0.46 & -0.84 & -0.11 \\
\hline SD & 0.52 & -0.79 & 0.30 & 0.88 & 0.17 & -0.43 & 0.92 & -0.28 & 0.25 \\
\hline TSW & -0.31 & 0.93 & 0.12 & -0.61 & -0.59 & 0.49 & -0.62 & 0.43 & -0.62 \\
\hline $\mathrm{Y}$ & 0.60 & -0.62 & 0.46 & 0.94 & -0.05 & -0.32 & 0.96 & -0.22 & 0.02 \\
\hline
\end{tabular}

Bold = correlation coefficients for $R^{2} \geq 0.50 ;{ }^{1}$ PD—number of pod; SD—number of seeds; TSW-Thousand Seed Weight.

Table A3. Spearman correlation matrix between nutrient accumulation, yield components and PCA factors.

\begin{tabular}{cccccccccc}
\hline \multirow{2}{*}{ Variable } & \multicolumn{3}{c}{ WOSR Total } & \multicolumn{3}{c}{ NRQ } & \multicolumn{3}{c}{ PNU } \\
\cline { 2 - 10 } & $\mathbf{P C 1}$ & $\mathbf{P C 2}$ & $\mathbf{P C 3}$ & $\mathbf{P C 1}$ & $\mathbf{P C 2}$ & $\mathbf{P C 3}$ & $\mathbf{P C 1}$ & PC2 & PC3 \\
\hline $\mathrm{N}$ & $\mathbf{0 . 8 4}$ & -0.36 & -0.28 & $\mathbf{- 0 . 8 4}$ & -0.10 & -0.23 & $\mathbf{0 . 8 5}$ & 0.20 & -0.05 \\
$\mathrm{P}$ & 0.44 & $\mathbf{0 . 7 9}$ & -0.35 & 0.14 & $\mathbf{- 0 . 7 8}$ & -0.50 & $\mathbf{0 . 8 6}$ & -0.39 & -0.13 \\
$\mathrm{~K}$ & $\mathbf{0 . 9 6}$ & 0.20 & 0.15 & $\mathbf{- 0 . 8 6}$ & -0.43 & 0.21 & $\mathbf{0 . 9 0}$ & 0.39 & 0.10 \\
$\mathrm{Mg}$ & $\mathbf{0 . 9 2}$ & 0.26 & 0.21 & $\mathbf{- 0 . 8 8}$ & 0.14 & -0.12 & $\mathbf{0 . 8 7}$ & 0.27 & -0.02 \\
$\mathrm{Ca}$ & 0.48 & $\mathbf{0 . 8 4}$ & 0.08 & $\mathbf{- 0 . 8 7}$ & -0.38 & 0.26 & $\mathbf{0 . 8 7}$ & 0.45 & 0.08 \\
$\mathrm{Zn}$ & 0.33 & $\mathbf{- 0 . 8 1}$ & -0.46 & -0.36 & 0.12 & $\mathbf{- 0 . 8 6}$ & -0.06 & -0.87 & -0.35 \\
$\mathrm{Mn}$ & 0.40 & -0.12 & -0.87 & -0.65 & 0.24 & -0.17 & 0.39 & 0.05 & $\mathbf{- 0 . 9 0}$ \\
$\mathrm{Cu}$ & $\mathbf{0 . 7 5}$ & 0.37 & -0.46 & $\mathbf{- 0 . 9 7}$ & 0.07 & 0.09 & 0.59 & 0.76 & -0.11 \\
$\mathrm{PD}$ & 0.57 & $\mathbf{- 0 . 7 9}$ & 0.00 & -0.59 & $\mathbf{0 . 7 1}$ & 0.26 & 0.16 & $\mathbf{- 0 . 9 7}$ & -0.02 \\
$\mathrm{SD}$ & $\mathbf{0 . 9 2}$ & -0.14 & 0.35 & 0.07 & $\mathbf{0 . 9 7}$ & -0.15 & $\mathbf{0 . 8 0}$ & -0.53 & 0.17 \\
$\mathrm{TSW}$ & -0.60 & 0.33 & $\mathbf{- 0 . 7 1}$ & -0.06 & $\mathbf{- 0 . 9 3}$ & -0.16 & -0.67 & 0.54 & -0.40 \\
$\mathrm{Y}$ & $\mathbf{0 . 9 8}$ & -0.07 & 0.11 & 0.02 & $\mathbf{0 . 8 9}$ & -0.29 & $\mathbf{0 . 7 5}$ & -0.51 & 0.02 \\
\hline
\end{tabular}

Bold = correlation coefficients for $R^{2} \geq 0.50 ;{ }^{1}$ PD—number of pod; SD—number of seeds; TSW-Thousand Seed Weight.

Table A4. Stepwise regression models of main variable response to the amount of nutrients accumulated in WOSR traits, $n=18$.

\begin{tabular}{cccccc}
\hline Plant Trait & Variable & Equation & No. & $\mathbf{R}^{\mathbf{2}}$ & $p \leq$ \\
\hline \multirow{4}{*}{ Total plant } & $\mathrm{Y}^{1}$ & $\mathrm{Y}=1076.5+164.6 \mathrm{Mg}$ & (A1) & 0.59 & 0.01 \\
biomass-flowering & $\mathrm{PD}$ & $\mathrm{PD}=7668+25.2 \mathrm{~N}-158.4 \mathrm{P}$ & (A2) & 0.83 & 0.001 \\
& $\mathrm{SD}$ & $\mathrm{SD}=37.3+4.77 \mathrm{Mg}-0.52 \mathrm{Ca}$ & (A3) & 0.75 & 0.001 \\
& $\mathrm{TSW}$ & $\mathrm{TSW}=4.68+0.024 \mathrm{P}-0.06 \mathrm{Mg}+0.13 \mathrm{Ca}$ & (A4) & 0.89 & 0.001 \\
\hline & $\mathrm{Y}$ & $\mathrm{Y}=323.5+40.8 \mathrm{~K}+198.5 \mathrm{Mg}$ & $(\mathrm{A} 5)$ & 0.98 & 0.001 \\
Seeds & $\mathrm{PD}$ & $\mathrm{PD}=2781-432 \mathrm{P}+260 . \mathrm{K}+672.3 \mathrm{Ca}$ & (A6) & 0.89 & 0.001 \\
& $\mathrm{SD}$ & $\mathrm{SD}=-1413.5+10049 \mathrm{Mg}-101 \mathrm{Mn}-$ & (A7) & 0.98 & 0.001 \\
& $\mathrm{TSW}$ & $\mathrm{TSW}=6.53+0.027 \mathrm{~N}-0.42 \mathrm{Mg}$ & (A8) & 0.98 & 0.001 \\
\hline & $\mathrm{Y}$ & $\mathrm{Y}=1329+7.4 \mathrm{~N}+6.3 \mathrm{~K}$ & (A9) & 0.93 & 0.001 \\
Post-harvest & $\mathrm{PD}$ & $\mathrm{PD}=1039+13.6 \mathrm{~K}+46.8 \mathrm{Zn}-1.4 \mathrm{Mn}$ & (A10) & 0.88 & 0.001 \\
residues & $\mathrm{SD}$ & $\mathrm{SD}=58.7+0.29 \mathrm{~K}-2.04 \mathrm{Cu}$ & (A11) & 0.92 & 0.001 \\
& $\mathrm{TSW}$ & $\mathrm{TSW}=4.25-0.008 \mathrm{~K}+0.11 \mathrm{Cu}$ & (A12) & 0.75 & 0.001 \\
\hline
\end{tabular}


Table A4. Cont.

\begin{tabular}{|c|c|c|c|c|c|}
\hline Plant Trait & Variable & Equation & No. & $\mathbf{R}^{2}$ & $p \leq$ \\
\hline \multirow{4}{*}{$\begin{array}{l}\text { Total plant } \\
\text { biomass-physiologic } \\
\text { maturity }\end{array}$} & $\mathrm{Y}$ & $\mathrm{Y}=1027+4.95 \mathrm{~N}+5.27 \mathrm{~K}$ & (A13) & 0.93 & 0.001 \\
\hline & PD & $\mathrm{PD}=625+10.3 \mathrm{~K}+25.7 \mathrm{Zn}-11.1 \mathrm{Mn}$ & (A14) & 0.89 & 0.001 \\
\hline & $\mathrm{SD}$ & $\mathrm{SD}=58.5+0.27 \mathrm{~K}-0.13 \mathrm{Ca}-1.0 \mathrm{Cu}$ & (A15) & 0.93 & 0.001 \\
\hline & TSW & $\mathrm{TSW}=3.8-0.007 \mathrm{~K}+0.8 \mathrm{Cu}$ & (A16) & 0.80 & 0.001 \\
\hline \multirow{4}{*}{$\begin{array}{c}\text { Nutrient } \\
\text { Remobilization } \\
\text { Quota, NRQ }\end{array}$} & $\mathrm{Y}$ & $\mathrm{Y}=3844-9.34 \mathrm{~K}+80.7 \mathrm{Cu}$ & (A17) & 0.79 & 0.001 \\
\hline & PD & $P D=7520+29.6 N-199.7 P$ & (A18) & 0.89 & 0.001 \\
\hline & SD & $\mathrm{SD}=69.3+0.26 \mathrm{~K}+2.21 \mathrm{Cu}$ & (A19) & 0.93 & 0.001 \\
\hline & TSW & $\mathrm{TSW}=4.96+0.035 \mathrm{P}+0.002 \mathrm{~K}-0.002 \mathrm{Mn}$ & $(\mathrm{A} 20)$ & 0.80 & 0.001 \\
\hline \multirow{4}{*}{$\begin{array}{l}\text { Post-flowering } \\
\text { Nutrient Uptake, } \\
\qquad \mathrm{PNa}_{\mathrm{a}}\end{array}$} & $\mathrm{Y}$ & $\mathrm{Y}=4755+8.2 \mathrm{~K}-71.3 \mathrm{Cu}$ & (A21) & 0.63 & 0.01 \\
\hline & PD & $\mathrm{PD}=6577+14.8 \mathrm{~K}+28 \mathrm{Zn}-177.9 \mathrm{Cu}$ & (A22) & 0.77 & 0.001 \\
\hline & $\mathrm{SD}$ & $\mathrm{SD}=96.4+0.25 \mathrm{~K}-2.13 \mathrm{Cu}$ & (A23) & 0.77 & 0.001 \\
\hline & TSW & $\mathrm{TSW}=6.02-0.06 \mathrm{P}+0.0032 \mathrm{Mn}$ & (A24) & 0.76 & 0.001 \\
\hline
\end{tabular}

\footnotetext{
${ }^{1}$ Y—seed yield; PD—Pod Density, SD—Seed Density; TSW—Thousand Seed Weight.
}

Table A5. Nutritional Harvest Index, \%.

\begin{tabular}{|c|c|c|c|c|c|c|c|c|c|}
\hline \multirow{2}{*}{$\begin{array}{c}\text { Year } \\
(\mathrm{Y})\end{array}$} & \multirow{2}{*}{$\begin{array}{c}\text { Factor } \\
\text { (F) }\end{array}$} & \multicolumn{5}{|c|}{ Macronutrients } & \multicolumn{3}{|c|}{ Micronutrients } \\
\hline & & $\mathbf{N}$ & $\mathbf{P}$ & $\mathbf{K}$ & Mg & $\mathrm{Ca}$ & $\mathrm{Zn}$ & Mn & $\mathrm{Cu}$ \\
\hline \multirow[t]{6}{*}{2008} & $\mathrm{AC}$ & $65.9 b$ & 66.9 & 10.5 & 40.3 & $5.1 \mathrm{a}$ & 65.5 & 43.3 & 29.1 \\
\hline & $\mathrm{NP}$ & $47.9 \mathrm{a}$ & 69.8 & 10.3 & 44.0 & $6.2 \mathrm{a}$ & 63.9 & 39.4 & 30.1 \\
\hline & NPK & $59.9 \mathrm{ab}$ & 64.8 & 9.6 & 44.1 & $5.9 \mathrm{a}$ & 67.2 & 39.0 & 28.1 \\
\hline & NPKMgS1 & $59.4 \mathrm{ab}$ & 66.9 & 8.7 & 42.2 & $5.1 \mathrm{a}$ & 64.9 & 38.4 & 27.8 \\
\hline & NPKMgS2 & $64.4 \mathrm{~b}$ & 65.4 & 9.2 & 44.7 & $6.1 \mathrm{a}$ & 68.0 & 40.0 & 29.1 \\
\hline & NPKMgS3 & $63.4 b$ & 68.4 & 8.7 & 43.3 & $5.7 \mathrm{a}$ & 67.0 & 33.8 & 27.1 \\
\hline \multicolumn{2}{|c|}{$F$-value } & $5.7^{* *}$ & 1.3 & 1.5 & 0.6 & 3.0 * & 1.0 & 2.6 & 0.9 \\
\hline \multicolumn{2}{|c|}{ SE } & 2.73 & 1.65 & 0.64 & 2.10 & 0.28 & 1.55 & 1.90 & 1.15 \\
\hline \multirow[t]{6}{*}{2009} & $\mathrm{AC}$ & 56.6 & 60.1 & $16.5^{\mathrm{b}}$ & 51.2 & 9.9 & 56.3 & $47.5 b$ & $37.2 \mathrm{ab}$ \\
\hline & $\mathrm{NP}$ & 54.7 & 55.9 & $10.6^{\mathrm{a}}$ & 55.3 & 10.4 & 56.4 & $45.9 b$ & $34.6 \mathrm{ab}$ \\
\hline & NPK & 52.1 & 59.9 & $9.4^{\mathrm{a}}$ & 49.6 & 11.8 & 54.3 & $43.2 \mathrm{a}$ & $31.9 \mathrm{a}$ \\
\hline & NPKMgS1 & 55.7 & 58.8 & $10.9^{a}$ & 56.3 & 11.4 & 53.1 & $45.1 \mathrm{a}$ & $36.1 \mathrm{ab}$ \\
\hline & NPKMgS2 & 52.8 & 64.6 & $10.4^{\mathrm{a}}$ & 59.3 & 12.2 & 58.6 & $43.2 \mathrm{a}$ & $38.5 b$ \\
\hline & NPKMgS3 & 55.2 & 59.3 & $9.9^{\mathrm{a}}$ & 57.6 & 10.2 & 55.2 & $35.0 \mathrm{a}$ & $33.1 \mathrm{ab}$ \\
\hline \multicolumn{2}{|c|}{$F$-value } & 0.9 & 1.7 & $6.1^{* *}$ & 2.5 & 2.0 & 0.4 & $3.6 *$ & $3.1 *$ \\
\hline \multicolumn{2}{|c|}{ SE } & 1.88 & 2.17 & 1.06 & 2.38 & 0.67 & 3.11 & 2.31 & 1.42 \\
\hline \multirow[t]{8}{*}{2010} & $\mathrm{AC}$ & 62.2 & 65.7 & 11.4 & $38.7 \mathrm{ab}$ & 6.8 & $46.7 \mathrm{ab}$ & 27.3 & $23.2 \mathrm{a}$ \\
\hline & $\mathrm{NP}$ & 60.9 & 68.2 & 11.2 & $40.0 \mathrm{ab}$ & 7.3 & $54.6 \mathrm{ab}$ & 22.7 & $31.6 \mathrm{ab}$ \\
\hline & NPK & 56.7 & 63.3 & 14.0 & $35.7 \mathrm{a}$ & 6.1 & $46.9 \mathrm{ab}$ & 18.4 & $29.7 \mathrm{ab}$ \\
\hline & NPKMgS1 & 67.1 & 75.2 & 14.7 & $53.5 b$ & 9.4 & $60.5 b$ & 25.2 & $37.2 b$ \\
\hline & NPKMgS2 & 66.7 & 65.6 & 10.5 & $37.5 \mathrm{a}$ & 8.0 & $51.4 \mathrm{ab}$ & 25.5 & $34.7 \mathrm{ab}$ \\
\hline & NPKMgS3 & 60.1 & 68.3 & 13.3 & $37.4 \mathrm{a}$ & 7.8 & $43.3 \mathrm{a}$ & 19.2 & $35.2 \mathrm{ab}$ \\
\hline & lue & 0.6 & 2.7 & 1.8 & $3.7 *$ & 1.8 & $3.3 *$ & 2.7 & $3.2^{*}$ \\
\hline & SE & 5.23 & 2.50 & 1.29 & 3.40 & 0.85 & 3.44 & 2.21 & 2.82 \\
\hline \multicolumn{2}{|l|}{$Y \times F$} & 1.4 & $2.5 *$ & $3.6^{* *}$ & $2.5^{*}$ & 1.8 & $2.2^{*}$ & 0.8 & $3.1^{* *}$ \\
\hline
\end{tabular}

$* * *, * *{ }^{*}$ significant at $p<0.001 ;<0.01 ;<0.05$, respectively; SE-Standard error; ${ }^{\text {a }}$ within a year, means within a column followed by the same letter indicate a lack of significant difference between the treatments. 
Table A6. Reutilization coefficients of pre-flowering nutrient resources in seeds, $\%$.

\begin{tabular}{|c|c|c|c|c|c|c|c|c|c|}
\hline \multirow{2}{*}{$\begin{array}{c}\text { Year } \\
(Y)\end{array}$} & \multirow{2}{*}{$\begin{array}{c}\text { Factor } \\
\text { (F) }\end{array}$} & \multicolumn{5}{|c|}{ Macronutrients } & \multicolumn{3}{|c|}{ Micronutrients } \\
\hline & & $\mathbf{N}$ & $\mathbf{P}$ & $\mathbf{K}$ & Mg & $\mathrm{Ca}$ & $\mathrm{Zn}$ & Mn & $\mathrm{Cu}$ \\
\hline \multirow[t]{6}{*}{2008} & $\mathrm{AC}$ & 19.5 & $10.0 \mathrm{a}$ & $-533.7 \mathrm{ab}$ & $-29.5 a$ & $-1477.6 a$ & $12.7 \mathrm{a}$ & $-36.4 b c$ & $-126.4 a$ \\
\hline & NP & 33.5 & $63.0 \mathrm{~b}$ & $-279.8 b$ & $65.7 \mathrm{~b}$ & $-842.5 b$ & $92.7 \mathrm{c}$ & $19.9 \mathrm{c}$ & $-29.0 b$ \\
\hline & NPK & 26.2 & $16.1 \mathrm{a}$ & $-559.4 \mathrm{ab}$ & $2.7 \mathrm{ab}$ & $-1188.1 \mathrm{ab}$ & $35.9 \mathrm{ab}$ & $-55.9 \mathrm{ab}$ & $-114.1 \mathrm{ab}$ \\
\hline & NPKMgS1 & 29.3 & $21.8 \mathrm{a}$ & $-702.0 \mathrm{a}$ & $11.9 \mathrm{ab}$ & $-1402.3 a$ & $41.6 \mathrm{ab}$ & $-49.2 \mathrm{ab}$ & $-122.9 \mathrm{ab}$ \\
\hline & NPKMgS2 & 39.7 & $25.6 a$ & $-497.9 \mathrm{ab}$ & $11.1 \mathrm{ab}$ & $-1055.4 \mathrm{ab}$ & $68.2 b c$ & $-52.1 \mathrm{ab}$ & $-95.1 \mathrm{ab}$ \\
\hline & NPKMgS3 & 33.8 & $22.3 a$ & $-689.9 a$ & $-10.7 a$ & $-1263.8 \mathrm{ab}$ & $36.5 \mathrm{ab}$ & $-107.5 \mathrm{a}$ & $-140.0 \mathrm{a}$ \\
\hline \multicolumn{2}{|c|}{$F$-value } & 0.4 & $6.9^{* *}$ & $3.5 *$ & $4.5^{* *}$ & $5.1 *$ & $7.1^{* * *}$ & $7.5^{* * *}$ & $3.6^{*}$ \\
\hline \multicolumn{2}{|c|}{ SE } & 11.7 & 7.24 & 81.9 & 15.0 & 103.0 & 10.5 & 14.9 & 21.0 \\
\hline \multirow[t]{6}{*}{2009} & $\mathrm{AC}$ & 67.1 & -3.0 & $571.5 \mathrm{~b}$ & 48.0 & -427.6 & -23.1 & $-9.9 \mathrm{ab}$ & 31.2 \\
\hline & $\mathrm{NP}$ & 102.9 & 14.1 & $137.6 a$ & 83.8 & -304.8 & 47.4 & $61.3 \mathrm{c}$ & 105.8 \\
\hline & NPK & 79.3 & 33.7 & $251.9 \mathrm{ab}$ & 88.2 & -77.9 & 11.1 & $-2.6 a b$ & 95.3 \\
\hline & NPKMgS1 & 109.9 & 17.0 & $262.3 \mathrm{ab}$ & 51.2 & -242.3 & 29.8 & $32.9 \mathrm{bc}$ & 87.1 \\
\hline & NPKMgS2 & 130.9 & 34.2 & $641.5 b$ & 84.3 & -32.6 & 54.0 & $84.4 \mathrm{c}$ & 172.3 \\
\hline & NPKMgS3 & 106.4 & 1.4 & 273.7ab & 76.4 & -218.7 & 22.1 & $-56.3 a$ & 90.3 \\
\hline \multicolumn{2}{|c|}{$F$-value } & 2.3 & 2.7 & $5.0 * *$ & 2.1 & 1.9 & 2.4 & ${\underset{* * *}{15.2}}$ & 1.6 \\
\hline \multicolumn{2}{|c|}{ SE } & 15.2 & 9.45 & 90.1 & 12.4 & 104.4 & 17.9 & 13.2 & 35.3 \\
\hline \multirow[t]{6}{*}{2010} & $\mathrm{AC}$ & 99.6 & 112.1 & 43.0 & $92.6 \mathrm{~b}$ & -346.5 & 63.8 & $-0.8 b$ & -135.7 \\
\hline & $\mathrm{NP}$ & 69.5 & 71.5 & 6.0 & $31.0 \mathrm{ab}$ & -674.4 & 75.8 & $-135.7 \mathrm{ab}$ & -79.4 \\
\hline & NPK & 51.4 & 60.8 & -16.7 & $11.9 \mathrm{ab}$ & -489.4 & 17.5 & $-282.1 \mathrm{a}$ & -73.6 \\
\hline & NPKMgS1 & 135.2 & 105.1 & 160.2 & 78.6ab & -581.2 & 75.3 & $-18.1 b$ & -14.4 \\
\hline & NPKMgS2 & 141.7 & 75.7 & -80.2 & $-17.4 a$ & -568.4 & 30.3 & $-7.7 \mathrm{~b}$ & -48.1 \\
\hline & NPKMgS3 & 95.6 & 83.5 & 173.8 & 49.4ab & -427.2 & 37.3 & $-144.8 \mathrm{ab}$ & 38.0 \\
\hline \multicolumn{2}{|c|}{$F$-value } & 1.8 & 2.5 & 1.3 & $3.3 *$ & 0.8 & 1.0 & $5.1^{* *}$ & 2.4 \\
\hline \multicolumn{2}{|c|}{ SE } & 26.4 & 12.7 & 89.3 & 22.7 & 135.5 & 25.5 & 49.2 & 38.6 \\
\hline$Y \times F$ & $F$-value & 0.7 & $3.1^{* *}$ & $2.8^{* *}$ & $4.1^{* * *}$ & 1.1 & 1.1 & $3.9^{* * *}$ & 0.9 \\
\hline
\end{tabular}

\section{References}

1. Abbadi, A.; Leckband, G. Rapessed breeding for oil content, quality, and sustainability. Eur. J. Lipid Sci. Technol. 2011, 113, 1198-1206. [CrossRef]

2. Berry, P.M.; Spink, J.H. A physiological basis of oilseed rape yields: Past and future. J. Agric. Sci. 2006, 144, 381-392. [CrossRef]

3. Pullens, J.W.M.; Sharif, B.; Trnka, M.; Balek, J.; Semenov, M.A.; Olesen, J.E. Risk factors for European winter oilseed rape production under climate change. Agric. For. Meteorol. 2019, 272-273, 30-39. [CrossRef]

4. Schulte auf'm Erley, G.; Behrens, T.; Ulas, A.; Wiesler, F.; Horst, W.J. Agronomic traits contributing to nitrogen efficiency of winter oilseed rape cultivars. Field Crop. Res. 2011, 124, 114-123. [CrossRef]

5. Wang, Y.; Liu, T.; Li, X.; Ren, T.; Cong, R.; Lu, J. Nutrient deficiency limits population development, yield formation and nutrient uptake of direct sown winter oilseed rape. J. Integr. Agric. 2015, 14, 670-680. [CrossRef]

6. FAOSTAT. Food and Agriculture Organization of the United Nations. Available online: http://faostat.fao.org/ site/567/default.aspx\#ancor (accessed on 25 September 2019).

7. Lu, H.; Lu, J.; Ren, T.; Li, X.; Cong, R. Nutrient efficiency of winter oilseed rape in an intensive cropping system: A regional analysis. Podosphere 2017, 27, 364-370.

8. Zajac, T.; Klimek-Kopyra, A.; Oleksy, A.; Lorenc-Kozik, A.; Ratajczak, K. Analysis of yield and plant traits of oilseed rape (Brassica napus L.) cultivated in temperate region in light of the possibilities of sowing in arid areas. Acta Agrobot. 2016, 69, 1696. [CrossRef]

9. Bouchet, A.-S.; Laperche, A.; Bissuel-Belaygue, C.; Snowdon, R.; Nesi, N.; Stahl, A. Nitrogen use eficiency in rapeseed. A review. Agron. Sustain. Dev. 2016, 36, 38. [CrossRef] 
10. Bartomeus, I.; Gagic, V.; Bommmarco, R. Pollinators, pests and soil properties interactively shape oilseed rape yield. Basic Appl. Ecol. 2015, 16, 737-745. [CrossRef]

11. Barłóg, P.; Grzebisz, W. Effect of timing and nitrogen fertilizer application on winter oilseed rape (Brassica napus L.). II. Nitrogen uptake dynamics and fertilizer efficiency. J. Agron. Crop Sci. 2004, 190, 314-323. [CrossRef]

12. Hoffmann, M.P.; Jacobs, A.; Whitbread, A.M. Crop modeling based analysis of site-specific production limitations of winter oilseed rape in northern Germany. Field Crop. Res. 2015, 178, 49-62. [CrossRef]

13. Grzebisz, W.; Szczepaniak, W.; Barłog, P.; Przygocka-Cyna, K.; Potarzycki, J. Phosphorus sources for winter oilseed rape (Brassica napus L.) during reproductive growth-magnesium sulfate management impact on $\mathrm{P}$ use efficiency. Arch. Agron. Soil Sci. 2018, 64, 1646-1662. [CrossRef]

14. Holmes, M.R.J. Nutrition of the Oilseed Rape Crop; Applied Science Publishers LTD: London, UK, $1980 ;$ p. 158.

15. Ren, T.; Lu, J.; Li, H.; Zou, J.; Xu, H.; Liu, X.; Li, X. Potassium-fertilizer management in winter oilseed-rape production in China. J. Plant Nutr. Soil Sci. 2013, 176, 429-440. [CrossRef]

16. Grzebisz, W. Crop response to magnesium fertilization as affected by nitrogen supply. Plant Soil 2013, 368, 23-39. [CrossRef]

17. Szczepaniak, W.; Barłóg, P.; Łukowiak, R.; Przygocka-Cyna, K. Effect of balanced nitrogen fertilization in four-year rotation on plant productivity. J. Cent. Eur. Agric. 2013, 14, 64-77. [CrossRef]

18. Diepenbrock, W. Yield analysis of winter oilseed rape (Brassica napus L.): A review. Field Crop. Res. 2000, 67, 35-49. [CrossRef]

19. Weymann, W.; Bottcher, U.; Sieling, K.; Kage, H. Effects of weather conditions during different growth phases on yield formation of winter oilseed rape. Field Crop. Res. 2015, 173, 41-48. [CrossRef]

20. Habekotté, B. Qantitative analysis of pod formation, seed set and seed filling in winter oilseed rape (Brassica napus L.) under field conditions. Field Crop. Res. 1993, 35, 21-33. [CrossRef]

21. Wang, X.; Mathieu, A.; Cournede, P.-H.; Allirand, J.-M.; Jullien, A.; de Reffye, P.; Zhang, B.G. Variability and regulation of the number of ovules, seeds, and pods according to assimilate availability in winter oilseed rape (Brassica napus L.). Field Crop. Res. 2011, 122, 60-69. [CrossRef]

22. Maillard, A.; Diquélou, S.; Billard, V.; Laîné, P.; Garnica, M.; Prudent, M.; Garcia-Mina, J.-M.; Yvin, J.-C.; Ourry, A. Leaf mineral nutrient remobilization during leaf senescence and modulation by nutrient deficiency. Front. Plant Sci. 2015, 6, 317. [CrossRef]

23. Peltonen-Sainio, P.; Jauhiainen, L. Association of growth dynamics, yield components and seed quality in long-term trials covering rapeseed cultivation history at high latitides. Field Crop. Res. 2008, 108, 101-108. [CrossRef]

24. Szczepaniak, W.; Grzebisz, W.; Potarzycki, J.; Łukowiak, R.; Przygocka-Cyna, K. Nutritional status of winter oilseed rape in cardinal stages of growth as yield indicator. Plant Soil Environ. 2015, 61, 291-296. [CrossRef]

25. Grzebisz, W. Magnesium. In Handbook of Plant Nutrition; Barker, A.V., Pilbeam, D.J., Eds.; CRC Press: Boca Raton, FL, USA, 2015; pp. 199-260.

26. Grzebisz, W.; Barłóg, P.; Kryszak, J.; Łukowiak, R. Pre-anthesis nutritional status of spelt wheat as a tool for predicting the attainable grain yield. Agronomy 2019, 9, 558. [CrossRef]

27. Smith, M.R.; Rao, I.M.; Merchant, A. Source-sink relationships in crop plants and their influence on yield development and nutritional quality. Front. Plant Sci. 2018, 9, 1889. [CrossRef]

28. Körner, C. Paradigm shift in plant growth control. Curr. Opin. Plant Biol. 2015, 25, 107-114. [CrossRef] [PubMed]

29. Barraclough, P.B. Root growth, macro-nutrient uptake dynamics and soil fertility requirements of a high-yeilding winter oilseed rape crop. Plant Soil 1989, 119, 59-70. [CrossRef]

30. Barłóg, P.; Grzebisz, W.; Diatta, J. Effect of timing and nitrogen fertilizers on nutrients content and uptake of winter oilseed rape. Part II. Dynamics of nutrients uptake. In Chemistry for Agriculture; Górecki, H., Dobrzański, Z., Kafarski, P., Eds.; Czech-Pol Trade: Prague, Czech Republic, 2005; Volume 6, pp. 113-123.

31. White, P. Long-distance transport in the xylem and phloem. In Marschner's Mineral Nutrition of Higher Plants; Marschner, P., Ed.; Elsevier: Amsterdam, The Netherlands, 2012; pp. 49-70.

32. Gammelvind, L.H.; Schjoerring, J.K.; Mogensen, V.O.; Jensen, C.R.; Bock, J.G.H. Photosynthesis in leaves and siliques of winter oilseed rape (Brassica napus L.). Plant Soil 1996, 186, 227-236. [CrossRef] 
33. Malagoli, M.; Laine, P.; Rossato, L.; Ourry, A. Dynamics of nitrogen uptake and mobilization in field-grown winter oilseed rape (Brassica napus L.) from stem extension to harvest. I. Global $\mathrm{N}$ flows between vegetative and reproductive tissues in relations to leaf fall and their residual N. Ann. Bot. 2005, 95, 853-861. [CrossRef]

34. Pan, Y.; Lu, Z.; Lu, J.; Li, X.; Cong, R. Effects of low sink demand on leaf photosynthesis under potassium deficiency. Plant Physiol. Biochem. 2017, 113, 110-121. [CrossRef]

(C) 2020 by the authors. Licensee MDPI, Basel, Switzerland. This article is an open access article distributed under the terms and conditions of the Creative Commons Attribution (CC BY) license (http://creativecommons.org/licenses/by/4.0/). 